\title{
Functional and Molecular Aspects of Glucocorticoids in the Endocrine Pancreas and Glucose Homeostasis
}

\author{
Alex Rafacho, Antonio C. Boschero and Henrik Ortsäter \\ Additional information is available at the end of the chapter
}

http://dx.doi.org/10.5772/50233

\section{Introduction}

As presented in the previous chapter, excessive exposure to endogenous or exogenous glucocorticoids (GCs) can disrupt glucose homeostasis in health individuals leading to glucose intolerance and/or insulin resistance (IR), and also aggravates the glucose metabolism in type 2 diabetic patients. In this context, we aim, in this chapter, to present and discuss the adaptive compensations in three levels: structural, functional and molecular - of the endocrine pancreas in response to the GC-induced IR and glucose intolerance that are required to maintain glycemia at physiological or near to physiological values. We will bring a comprehensive summary on experimental and clinical investigations performed in humans, rats and mice. Species differences will receive a special focus since the literature regarding humans, rats and mice responses to GC treatment indicates that there are species differences in both response to and sensitivity towards CGs.

\section{Effect of glucocorticoids on the endocrine pancreas}

GC hormones are secreted by the adrenal cortex under control of the HPA axis. This class of hormones plays an important role on energy homeostasis by modulating glucose, lipid and protein metabolism. The HPA axis may receive several inputs during some stressful conditions, such as fasting, physical activities as well as emotional episodes. In such conditions, the physiological GC actions guarantee adequate substrate supply for oxidative metabolism by increasing hepatic glucose production, lipolysis and proteolysis (Andrews \& Walker, 1999).

Alterations in peripheral insulin sensitivity are reciprocally related to pancreatic islet function, in that insulin secretion is initially adaptively increased in response to conditions 
of IR (e.g., obesity, pregnancy, pre-diabetes) (Kahn et al., 1993). As GCs induce IR, pancreatic $\beta$-cells initially also increase their insulin secretion capacity in response to GC treatment (Beard et al., 1984; Nicod et al., 2003; Ahrén, 2008; Rafacho et al., 2008; Rafacho et al., 2010). However, it is also known that GCs, by direct effects, can cause pancreatic $\beta$-cell dysfunction, which leads to attenuated GSIS (Lambillotte et al., 1997; Jeong et al., 2001; Ullrich et al., 2005; Zawalich et al., 2006; Roma et al., 2011). The crucial point is that, at least during short (2 to 15 days) periods of treatment, the direct negative effects of GCs are not reproduced on pancreatic $\beta$-cell during in vivo GC administration to normal subjects, and the derangement of $\beta$-cells during GC treatment seems to depend on predispositions such as genetic background (Ogawa et al., 1992), age (Novelli et al., 1999) as well as previous glucose intolerance and/or low insulin sensitivity (Wajngot et al., 1992; Ohneda et al., 1993; Henriksen et al., 1997; Larsson \& Ahren, 1999; Besse et al., 2005). In the next topic, we will discuss in detail the endocrine pancreas and glucose homeostasis profile both in human and in rodent experimental models of GC treatment. In addition, results of in vitro studies in which primary $\beta$-cells or insulin-producing cells have been exposed to GCs will be discussed.

\subsection{GC treatment and glucose tolerance, insulin sensitivity and $\beta$-cell function in humans}

\subsubsection{Acute GC effects in healthy individuals}

The acute effects of GCs in healthy individuals, as judged by cortisol infusion (Shamoon et al., 1980) or by high doses of prednisolone (Kalhan \& Adam, 1975; van Raalte et al., 2010), seem to be inhibitory for insulin secretion. This is based on the fact that circulating insulin levels during fasting state are not altered following GC treatment, despite the increase in blood glucose levels. The increase in glycemia is associated with decreased glucose uptake and clearance, whereas the rates of endogenous glucose production are unchanged (Shamoon et al., 1980). Glucose intolerance is observed during an oral glucose tolerance test (oGTT) in healthy individuals receiving a single oral dose of $1 \mathrm{mg}$ dexamethasone (DEX) just prior to the oGTT. In the latter, glucose intolerance was also a result of decreased glucose clearance; while no differences in endogenous glucose production was observed too (Schneiter \& Tappy, 1998). Although the literature concerning rapid GC effects on insulin secretion in healthy individuals is scarce, it seems that insulin secretion under glucose infusion is reduced (Shamoon et al., 1980) or unaltered (Schneiter \& Tappy, 1998) in response to a glucose challenge, suggesting an acute inhibitory effect of the GCs on $\beta$-cells (Kalhan \& Adam, 1975). It should also be mentioned that adaptive compensation to short GC exposures are transitory and usually reversible after discontinuation of steroid treatment (van Raalte et al., 2010).

\subsubsection{GC effects during prolonged exposure in healthy individuals}

Treatment of healthy subjects with high doses of DEX (2 to 4 days) or prednisolone (6 to 15 days) is associated with normoglycemia or modest increase in fasting blood glucose levels 
concomitant with significantly heightened circulating insulin concentrations during the post-absorptive state (Pagano et al., 1983; Beard et al., 1984; Grill et al., 1990; Schneiter \& Tappy, 1998; Hollingdal et al., 2002; Willi et al., 2002; Nicod et al., 2003; Binnert et al., 2004; van Raalte et al., 2010), (see an overview in Table 1). The elevation of insulinemia indicates IR, a condition also confirmed after GC treatment (Pagano et al., 1983; Grill et al., 1990; Larsson \& Ahren, 1999; Hollingdal et al., 2002; Willi et al., 2002; Nicod et al., 2003; Ahrén, 2008). The modest increase in fasting glycemia may be explained by direct effect of GCs on hepatic de novo glucose production or by a reduction of glucose uptake by peripheral tissues (e.g., muscle, liver and adipose tissue). In this case, even high levels of insulin (Schneiter \& Tappy, 1998) are insufficient to compensate for IR evoked by the steroid treatment. However, it must be stressed that most studies with GC administration for a short period in healthy volunteers do not show fasting hyperglycemia (Nicod et al., 2003; Binnert et al., 2004; Ahrén, 2008; van Raalte et al., 2010). Under glucose challenging by hyperglycemicclamp (Beard et al., 1984; Nicod et al., 2003; Binnert et al., 2004) or an oGTT (Schneiter \& Tappy, 1998; Hollingdal et al., 2002; Willi et al., 2002), insulin secretion is higher in GCtreated healthy subjects compared with control individuals. This increase in insulin secretion appears to be sufficient to maintain glucose homeostasis (Nicod et al., 2003; Binnert et al., 2004; Ahrén, 2008), suggesting that for the period of steroid exposure observed in the above studies the islets adjust their insulin release to overcome the IR imposed by GC treatment. However, we cannot exclude the possibility that at a more prolonged exposure (months or even years as in patients subjected to chronic GC therapies) $\beta$-cell dysfunction develops in face of sustained IR and/or by direct negative effects of GCs on $\beta$-cell function/viability resulting in dysregulation of glucose homeostasis.

The increased insulin secretion noted during GC treatment needs not necessarily result from a direct GC action on $\beta$-cells. This is suggested as several changes, such as in substrates, hormones, and/or neural influences that $\beta$-cells are exposed to, precluding a clear explanation of the factors causing increased islet function. Ahrén (Ahrén, 2008) performed an elegant experiment in which healthy women were subjected to oral DEX administration in a dose and period that resulted in IR, and insulin hypersecretion in response to arginine infusion. After 3 to 6 months, the same volunteers were treated with the same steroid regimen, but also received an intravenous infusion of a ganglionic antagonist (trimethaphan), which interrupts neural transmission. Arginine-stimulated insulin secretion was higher in DEX-treated individuals, as expected, but was markedly inhibited by the ganglionic antagonist. These data imply that a stimulus triggered by IR increases the parasympathetic tone to the islet $\beta$-cells to increase insulin secretion and this may contribute to the adaptive hypersecretion of insulin during IR (Ahrén, 2008). Whether this autonomic effect involves the classical neuropeptide acetylcholine, or any of the other parasympathetic neuropeptides, remains to be investigated (Ahrén, 2008).

In summary, the product of insulin secretion and peripheral insulin sensitivity, also called the disposition index, remains constant in healthy subjects exposed to GC treatment. 


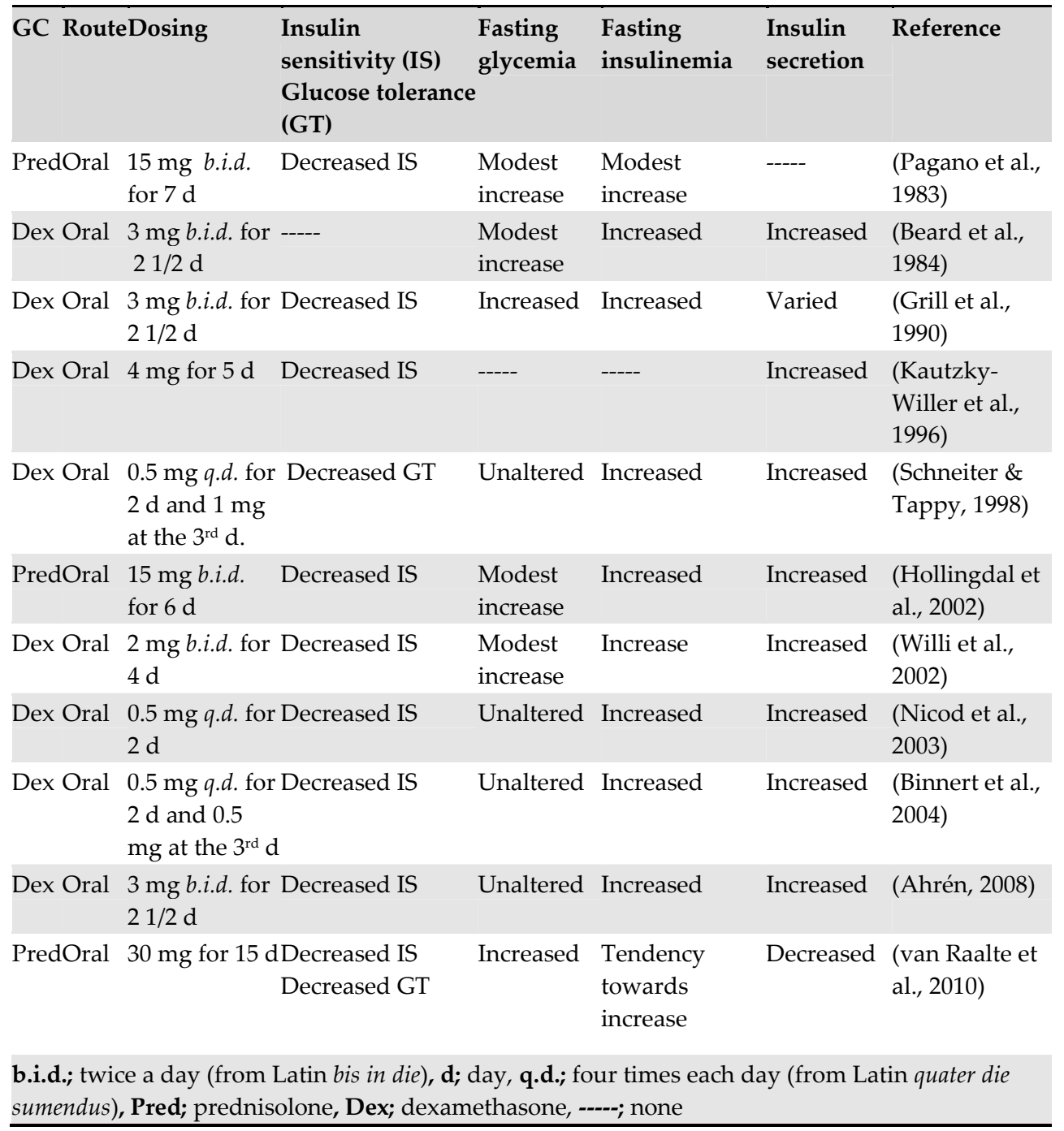

Table 1. Effects of prolonged GC treatment on glucose homeostasis in healthy volunteers.

\subsubsection{GC effects in susceptible subjects}

Administration of GCs to individuals with any degree of susceptibility towards glucose intolerance, but still normoglycemic, before treatment with GCs, such as those with low insulin sensitivity (Larsson \& Ahren, 1999) or with low insulin response to glucose (Wajngot et al., 1992), obese women (Besse et al., 2005) and first-degree relatives of patients with type 2 diabetes mellitus (T2DM) (Henriksen et al., 1997), fails to induce the adaptive islet compensation observed in healthy subjects. Thus, in such individuals GC treatment may 
disrupt glucose homeostasis and cause hyperglycemia. The derangements that contribute to glucose intolerance include reduction in glucose-dependent or arginine-induced insulin release (Larsson \& Ahren, 1999), increased glucose production and decreased glucose clearance (Wajngot et al., 1992), and reduction in whole body glucose disposal (Besse et al., 2005). Therefore, the enhancement in $\beta$-cell response, required to accommodate the GCinduced IR state, is impaired in these subjects.

\subsubsection{Obstacles for the investigation of $\beta$-cell function in humans}

The prolonged period of GC therapy utilized in clinical practice may surpass the short period used for experimental approaches in human studies that often is restricted to 2-15 days of GC treatment (van Raalte et al., 2009). Thus, the data from human experimental models, although of great relevance, fail to mimic the conditions of clinical practice. Elaboration of chronic GC protocols to investigate $\beta$-cell function in human volunteers is not feasible in consideration of the risk to develop irreversible adverse effects, ethical issues, as well as the nature of ex vivo and in vitro tools available for the mechanistic comprehension of $\beta$-cell function and growth (van Raalte et al., 2009). Yet, patients exhibiting excess of endogenous or exogenous GCs generally develop other side effects or altered circulating factors that could mask the GC effects on $\beta$-cell function (Dessein \& Joffe, 2006).

Taken together, acute GC administration seems to exert an inhibitory effect on insulin secretion, while prolonged exposure induces alterations in $\beta$-cell function as an adaptive compensation to surpass GC-induced IR. However, susceptible subjects are prone to develop $\beta$-cell dysfunction with subsequent impairment of glucose homeostasis. Considering that mechanistic investigations require ex vivo and in vitro approaches, and that rodent models exhibit similar responses as humans in terms of insulin secretion and glucose homeostasis profile, use of experimental rodent models has been important for understanding $\beta$-cell function during GC treatments.

\subsection{GC treatment and glucose tolerance, insulin sensitivity and $\beta$-cell function in rodents}

The effects of GCs on insulin secretion have been assessed in vivo and ex vivo in rats and mice and show that the compensatory islet responses in rats are similar to those observed in human volunteers. The importance of endogenous GCs was demonstrated in rats (Borelli et al., 1982) with bilateral adrenalectomy. These rats exhibit impaired insulin secretion in vivo in response to glucose, which is corrected by GC replacement. The endocrine pancreas adaptations to GC administration are not similar between rats and mice and for this reason we will first discuss the literature obtained with rat models and then proceed to mouse models.

\subsubsection{Acute GC effects in normal rats}

When administered acutely (4 to 6 hours), DEX causes a modest decrease in insulin sensitivity (Qi et al., 2004) or increased rate of glucose disappearance (Stojanovska et al., 
1990). This remains controversial, but at any rate it is accompanied by normoglycemia (Stojanovska et al., 1990; Qi et al., 2004) together with normal (Qi et al., 2004) or increased plasma insulin values (Stojanovska et al., 1990). These data reveal no deleterious effect of DEX on the insulinogenic index (the ratio between insulinemia and glycemia) when the steroid is acutely administered in rats.

\subsubsection{Glucose tolerance and insulin sensitivity in GC-treated rats}

The majority of the studies using rat models are performed with prolonged exposure to GCs and DEX is the compound preferentially employed. The protocols vary in dose $(0.01$ to 5 $\mathrm{mg} / \mathrm{kg}$, b.w.), duration (1 day to 8 weeks) and administration route (subcutaneous, intramuscular, intraperitoneal, oral), gender, age, and strain (Lee et al., 1989; O'Brien et al., 1991; Koranyi et al., 1992; Ohneda et al., 1993; Wang et al., 1994; Novelli et al., 1999; Holness \& Sugden, 2001; Karlsson et al., 2001; Choi et al., 2006; Wierup et al., 2006; Rafacho et al., 2008; Rafacho et al., 2011) (Table 2). Similar to humans, normal rats treated with DEX had decreased peripheral insulin sensitivity. This GC-induced IR is time-, dose- and agedependent (Novelli et al., 1999; Rafacho et al., 2008; Rafacho et al., 2011) and is a common effect in GC-treated rats. This is supported by the fact that most studies showed fasting hyperinsulinemia, an indicator of IR (Lee et al., 1989; Stojanovska et al., 1990; Koranyi et al., 1992; Novelli et al., 1999; Zakrzewska et al., 1999; Barbera et al., 2001; Holness \& Sugden, 2001; Karlsson et al., 2001; Severino et al., 2002; Choi et al., 2006; Giozzet et al., 2008; Rafacho et al., 2008; Rafacho et al., 2010). This rise in circulating insulin concentrations fully compensates for peripheral IR in normal rats and prevents any increase in blood glucose concentrations (Lee et al., 1989; Koranyi et al., 1992; Ogawa et al., 1992; Novelli et al., 1999; Zakrzewska et al., 1999; Barbera et al., 2001; Holness \& Sugden, 2001; Severino et al., 2002; Choi et al., 2006; Giozzet et al., 2008; Rafacho et al., 2008; Rafacho et al., 2010), except in normal elderly rats (Novelli et al., 1999) or when the highest experimental doses $(1 \mathrm{mg} / \mathrm{kg}$. b.w.) and/or duration (four days or more) of DEX administration are used. However, these latter experimental conditions provoke only a slight elevation in blood glucose levels that do not exceed an average value of $7.5 \mathrm{mM}$ (Stojanovska et al., 1990; Holness \& Sugden, 2001; Holness et al., 2005; Rafacho et al., 2008; Rafacho et al., 2010). The glucose tolerance in GCtreated rats also varies depending on the dose, duration or predisposing factors (e.g., pregnancy, obesity and aging) (Novelli et al., 1999; Holness \& Sugden, 2001). Normal male adult rats receiving $0.1,0.5$ or $1 \mathrm{mg} / \mathrm{kg} b . w$. of DEX for 1 to 3 days do not exhibit glucose intolerance during a glucose load; however, when these rats are submitted to 5 days of DEX treatment at $1 \mathrm{mg} / \mathrm{kg}$ b.w. they become glucose intolerant (Rafacho et al., 2008). Thus, for low doses and/or short periods of GC administration, the elevation in insulin secretion is sufficient to prevent any derangement in glucose homeostasis. However, for higher doses and/or prolonged periods of GC treatment, these normal rats are unable to fully compensate for the metabolic demand and glucose intolerance appears, despite the marked increase in insulin response to glucose. Whether increased levels of lipids, like non-esterified fatty acids (NEFA), contribute to this metabolic perturbation deserves investigation, but there is already evidence that increased lipolysis may affect insulinogenic index under GC-induced IR in normal rats (Novelli et al., 2008). It is also 
important to mention that GC-treated elderly rats (Novelli et al., 1999), high-fat diet rats (Holness et al., 2005) or pregnant rats (Holness \& Sugden, 2001) become intolerant to glucose after a sugar challenge that is associated with a decreased insulinogenic index. Notably, all above alterations by GC treatment are transitory and normalized after discontinuation of steroid administration in healthy rats (Rafacho et al., 2010).

\begin{tabular}{|c|c|c|c|c|c|c|}
\hline GC R I & Dosing & $\begin{array}{l}\text { Insulin } \\
\text { sensitivity (IS) } \\
\text { Glucose } \\
\text { tolerance (GT) }\end{array}$ & $\begin{array}{l}\text { Fasting } \\
\text { glycemia }\end{array}$ & $\begin{array}{l}\text { Fasting } \\
\text { insulinemia }\end{array}$ & Insulin secretion & Reference \\
\hline 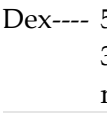 & $\begin{array}{l}5 \mu \mathrm{g} \text { b.i.d. for } \\
3 \text { or } 4 \mathrm{~d} \text { in } \\
\text { male SD }\end{array}$ & Decreased IS & Modest increase & Increased & Increased & $\begin{array}{l}\text { (Stojanovska } \\
\text { et al., 1990) }\end{array}$ \\
\hline Dexi.p 2 & $\begin{array}{l}2 \mathrm{mg} / \mathrm{kg} b . w . \\
\text { for } 7 \mathrm{~d} \text { in } \\
\text { female SD }\end{array}$ & ----- & ---- & ----- & $\begin{array}{l}\text { Increased } 1^{\text {st }} \\
\text { phase, but not } 2^{\text {nd }} \\
\text { in isolated islets }\end{array}$ & $\begin{array}{l}\text { (O'Brien et } \\
\text { dal., 1991) }\end{array}$ \\
\hline Dexi.p. $\frac{5}{2}$ & $\begin{array}{l}5 \mathrm{mg} / \mathrm{kg} \text { for } \\
24 \mathrm{~d} \text { (male } \\
\text { and female?) }\end{array}$ & $\begin{array}{l}\text { Decreased IS in } \\
\text { normal animals }\end{array}$ & Unaltered & ----- & Increased & $\begin{array}{l}\text { (Ogawa et al., } \\
1992 \text { ) }\end{array}$ \\
\hline Dex--- & $\begin{array}{l}0.125 \mathrm{mg} / \mathrm{kg} \\
\text { b.w. b.i.d. for } 4 \\
\mathrm{~d} \text { in male SD }\end{array}$ & ---- & Unaltered & Increased & ----- & $\begin{array}{l}\text { (Koranyi et } \\
\text { al., 1992) }\end{array}$ \\
\hline $\begin{array}{r}\text { Dexs.c. } \\
\mathrm{f} \\
-\end{array}$ & $\begin{array}{l}4 \mathrm{mg} / \mathrm{kg} \text { b.w. } \\
\text { for } 10 \mathrm{~d} \\
---\end{array}$ & ----- & ----- & ----- & Increased & $\begin{array}{l}\text { (Wang et al., } \\
\text { 1994) }\end{array}$ \\
\hline & $\begin{array}{l}0,125 \mathrm{mg} / \mathrm{kg} \\
\text { b.w. for } 13 \mathrm{~d} \\
\text { in } 3-, 18 \text { - and } \\
26-\text { month old } \\
\text { in male SD }\end{array}$ & ----- & $\begin{array}{l}\text { Unaltered for 3- } \\
\text { month old and } \\
\text { marked increase } \\
\text { for 18- and 26- } \\
\text { month old }\end{array}$ & $\begin{array}{l}\text { Increased in } \\
\text { age- } \\
\text { dependent } \\
\text { manner }\end{array}$ & $\begin{array}{l}\text { Increased mainly } \\
\text { in young animals } \\
\text { and in less extent } \\
\text { in olders }\end{array}$ & $\begin{array}{l}\text { (Novelli et al., } \\
\text { 1999) }\end{array}$ \\
\hline Dexi.p. 2 & $\begin{array}{l}2 \mathrm{mg} / \mathrm{kg} \text { b.w. } \\
\text { for } 12 \mathrm{~d} \text { in } \\
\text { female SD }\end{array}$ & ----- & $\begin{array}{l}\text { Fed moderate } \\
\text { hyperglycemia }\end{array}$ & Fed increase & Increased & $\begin{array}{l}\text { (Karlsson et } \\
\text { al., 2001) }\end{array}$ \\
\hline Dexs.c. & $\begin{array}{l}100 \mu \mathrm{g} / \mathrm{kg} b . w \\
\text { for } 6 \mathrm{~d} \text { in non- } \\
\text { pregnant } \\
\text { Wistar }\end{array}$ & $\begin{array}{l}\text { Modest decrease } \\
\text { in GT }\end{array}$ & Unaltered & Increased & Increased & $\begin{array}{l}\text { (Holness \& } \\
\text { Sugden, 2001) }\end{array}$ \\
\hline Dexs.c. 1 & $\begin{array}{l}1 \mu \mathrm{g} \text { b.i.d. for } \\
4 \mathrm{wk}\end{array}$ & Decreased IS & Unaltered & Increased & Increased & $\begin{array}{l}\text { (Severino et } \\
\text { al., 2002) }\end{array}$ \\
\hline Dexoral & $\begin{array}{l}110 \text { or } 100 \mu g \\
/ \mathrm{kg} b . w . \text { for } 8 \\
\text { wk in male } \\
\text { SD }\end{array}$ & Decreased IS & Unaltered & $\begin{array}{l}\text { Increased for } \\
\text { both }\end{array}$ & ----- & $\begin{array}{l}\text { (Choi et al., } \\
2006)\end{array}$ \\
\hline $\begin{array}{r}\text { Dexi.p. } \\
1 \\
5\end{array}$ & $\begin{array}{l}0.1,0.5 \text { or } 1 \\
\mathrm{mg} / \mathrm{kg} b . w . \text { for } \\
5 \mathrm{~d} \text { on Wistar }\end{array}$ & $\begin{array}{l}\text { Decreased } \\
\text { IS in all } \\
\text { Decreased GT } \\
(0.5 \text { and } 1 \mathrm{mg})\end{array}$ & $\begin{array}{l}\text { Modest increase } \\
\text { with high dose }\end{array}$ & $\begin{array}{l}\text { Dose- } \\
\text { dependent } \\
\text { increase }\end{array}$ & $\begin{array}{l}\text { Increased dose } \\
\text { dependently }\end{array}$ & $\begin{array}{l}\text { (Rafacho et } \\
\text { al., 2008) }\end{array}$ \\
\hline
\end{tabular}




\begin{tabular}{|c|c|c|c|c|c|c|}
\hline GC R & Dosing & $\begin{array}{l}\text { Insulin } \\
\text { sensitivity (IS) } \\
\text { Glucose } \\
\text { tolerance (GT) }\end{array}$ & $\begin{array}{l}\text { Fasting } \\
\text { glycemia }\end{array}$ & $\begin{array}{l}\text { Fasting } \\
\text { insulinemia }\end{array}$ & Insulin secretior & Reference \\
\hline Dexi.p & $\begin{array}{l}0.125 \mathrm{mg} / \mathrm{kg} \\
\text { b.w. for } 20 \mathrm{~d} \\
\text { in SD }\end{array}$ & Decreased IS & Unaltered & Increased & Increased & $\begin{array}{l}\text { (Novelli et al., } \\
\text { 2008) }\end{array}$ \\
\hline Dexi.p. & $\begin{array}{l}0.2 \mathrm{mg} / \mathrm{kg} b . w . \\
\text { for } 2 \mathrm{~d} \text { in male } \\
\text { Wistar }\end{array}$ & ---- & Modest increase & Increased & Increased & $\begin{array}{l}\text { (Sood \& } \\
\text { Ismail-Beigi, } \\
\text { 2010) }\end{array}$ \\
\hline Dexi.p. & $\begin{array}{l}1 \mathrm{mg} / \mathrm{kg} b . w . \\
\text { for } 1,3 \text { or } 5 \mathrm{~d} \\
\text { in male } \\
\text { Wistrar }\end{array}$ & $\begin{array}{l}\text { Decreased } \\
\text { IS - } 3 \text { and } 5 d \\
\text { Decreased } \\
\text { GT }-5 d\end{array}$ & $\begin{array}{l}\text { Tendency } \\
\text { towards on } 5 \mathrm{~d}\end{array}$ & $\begin{array}{l}\text { Time- } \\
\text { dependent } \\
\text { increase }\end{array}$ & Increased in all & $\begin{array}{l}\text { (Rafacho et } \\
\text { al., 2011) }\end{array}$ \\
\hline
\end{tabular}

R; route, b.i.d.; twice a day (from Latin bis in die), d; day, Dex; dexamethasone, SD; Sprague-Dawley, --$--;$ none

Table 2. Effects of prolonged GC treatment in normal rats on endocrine pancreas parameters.

\subsubsection{Ex vivo insulin secretion by isolated islets from GC-treated rats}

Islet insulin secretion in response to several stimuli, especially glucose, has been found to be reduced (Ogawa et al., 1992; Ohneda et al., 1993), unchanged (Chuthaputti \& Fletcher, 1987; O'Brien et al., 1991) or increased (Wang et al., 1994; Novelli et al., 1999; Barbera et al., 2001; Karlsson et al., 2001; Giozzet et al., 2008; Rafacho et al., 2008; Rafacho et al., 2009; Rafacho et al., 2010; Sood \& Ismail-Beigi, 2010; Rafacho et al., 2011) in GC-treated rats. The abrogation of insulin secretion by glucose is observed in Wistar rats vulnerable to GC treatment (that develop a diabetic profile after steroid treatment) (Ogawa et al., 1992) or in a Zucker fatty strain (fa/fa) (Ogawa et al., 1992; Ohneda et al., 1993). In islets from these rats, a chronological association between reductions in glucose transporter (GLUT)-2 immunolocalization in $\beta$-cells and glucose uptake in islets with the development of hyperglycemia is found (Ohneda et al., 1993). The reduction of GLUT2 could however not fully explain the total loss of GSIS in these rats if one considers that the remaining $\beta$-cells with intact GLUT2 distribution maintain a normal insulin response to glucose. These findings, if reproduced in humans, speak against the use of GCs in conditions where the insulin demand is already increased prior to GC treatment.

The most prominent functional islet adaptation, when rats are challenged with steroids, is the increased insulin response to glucose. This adaptation most likely occurs to compensate for GC-induced IR. This enhancement of $\beta$-cell function, also observed in humans, is anticipated in healthy individuals and guarantees a regular disposition index (the product of insulin secretion and peripheral insulin sensitivity). Figure 1 shows an overview of some already known mechanisms involved in this enhanced islet function and the proposed modes of interference by GC treatment. The $\beta$-cell possesses a unique signal transduction system dependent on metabolism of fuel stimuli to initiate insulin secretion (Matschinsky, 1996). Glycolytic and oxidative metabolism accelerates the generation of adenosine 
triphosphate (ATP). A rise in the cytosolic ATP/adenosine diphosphate (ADP) ratio is believed to close metabolically sensitive $\mathrm{K}^{+}$channels (KATP channels), leading to depolarization of the $\beta$-cell membrane. This activates voltage-gated $\mathrm{Ca}^{2+}$ channels and elevates intracellular $\mathrm{Ca}^{2+}$ concentration $\left(\left[\mathrm{Ca}^{2+}\right] \mathrm{i}\right)$, and culminates in the exocytosis of insulincontaining granules. In addition, elevation of $\left[\mathrm{Ca}^{2+}\right]_{i}$ activates a number of potentiating signaling pathways, including protein kinase A (PKA) and protein kinase C (PKC), which amplify insulin release (Nesher et al., 2002).

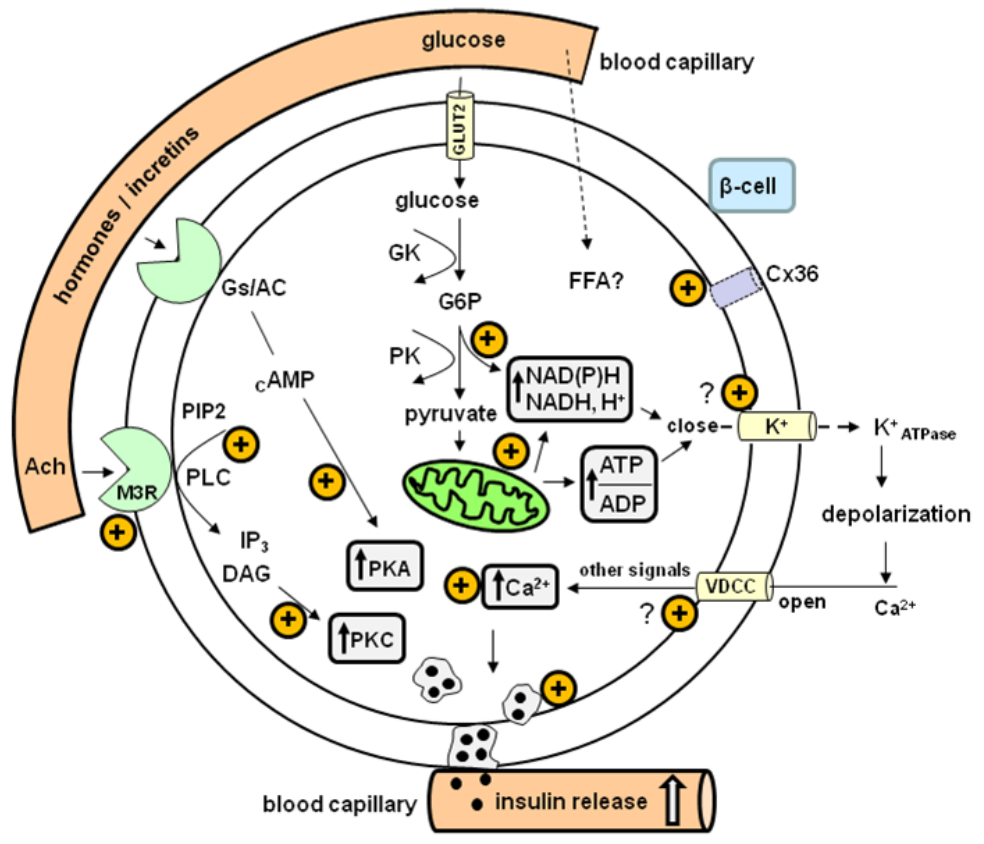

Figure 1. Insulin secretory process in $\beta$-cells from GC-treated rats. The known components involved in the adaptive increase in $\beta$-cell function after GC treatment are highlighted with a positive signal (orange circle), which indicates increased content or activity of the component after GC treatment. Most notably, increased glucose metabolism and cholinergic pathway activity cause increased calcium influx and insulin secretion. Abbreviations: AC, adenylyl cyclase; Ach, acetylcholine; ADP, adenosine diphosphate; ATP, adenosine triphosphate; cAMP, cyclic adenosine monophosphate; Cx36, connexin 36; DAG, diacylglycerol; FFA, free fatty acids; G6P, glucose-6-phosphatase; Gs. G-coupled stimulatory protein; GK, glucokinase; GLUT2, glucose transporter 2; IP3, inositol trisphosphate; M3R, muscarinic receptor type 3; $\mathrm{NADH}$, nicotinamide dinucleotide; $\mathrm{NAD}(\mathrm{P}) \mathrm{H}$, nicotinamide adenonine dinucleotide phosphate; PIP2, phosphatidylinositol bisphosphate; PK, pyruvate kinase; PKA, protein kinase A; PKC, protein kinase C; PLC, phospholipase C; VDCC, voltage-dependent calcium channel. Modified from Nussey \& Whitehead, 2001; Endocrinology: An integrated approach, box 2.19 (Nussey \& Whitehead, 2001).

The establishment of any direct GC effects on $\beta$-cells under in vivo conditions is difficult, since systemic metabolic consequences of GC treatment (e.g., circulating factors changing such glucose, NEFA, and other metabolites and hormones) probably interfere with GCmediated changes in $\beta$-cell function (van Raalte et al., 2009). Islets isolated from GC-treated 
rats have enhanced glucose responsiveness (Novelli et al., 1999; Barbera et al., 2001; Karlsson et al., 2001; Rafacho et al., 2008; Sood \& Ismail-Beigi, 2010), higher glucose sensitivity (lower EC50 values to glucose) (Giozzet et al., 2008; Rafacho et al., 2008), and exhibit pronounced first and second phase insulin secretion in response to glucose (Rafacho et al., 2008; Rafacho et al., 2011). The glycolytic components seem not to be involved in such augmented insulin response, since mRNA and protein contents of GLUT2, glucokinase (GK) and pyruvate kinase (PK) are unaltered in islets from DEX-treated rats (Rafacho et al., 2010; Sood \& Ismail-Beigi, 2010). However, these data do not exclude that GK and/or PK activities may be elevated since enzymatic activities have not been measured directly. Indirect determination of reduced nicotinamide adenine dinucleotide phosphate [NAD $(\mathrm{P}) \mathrm{H}]$ generation and mitochondrial function, by $\mathrm{NAD}(\mathrm{P}) \mathrm{H}$ autofluorescence and rhodamine 123 fluorescence, respectively, indicate increased glucose metabolism in islets from GC-treated rats (Rafacho et al., 2010). These authors did not determine the islet ATP content but found augmented $\left[\mathrm{Ca}^{2+}\right]_{i}$ in response to glucose that was not a result of elevated basal $\left[\mathrm{Ca}^{2+}\right]_{\mathrm{i}}$. The glucose-induced elevation in $\left[\mathrm{Ca}^{2+}\right]$ i appeared not to involve significant changes in KATP channels or voltage-gated $\mathrm{Ca}^{2+}$ channels response, since islets from DEX-treated rats perfused with high $\mathrm{K}^{+}$or tolbutamide did not show higher $\left[\mathrm{Ca}^{2+}\right]$ i compared to control islets. These data give a clear indication of enhanced glucose sensitivity in islets from GC-treated rats. The amplifying pathway of GSIS, which involves activation of $\mathrm{Ca}^{2+}$-dependent kinases, is altered in GC-treated rat islets. DEX-treated rats have high islet content of phosphorylated PKC $\alpha$ protein that is associated with increased number of docked insulin-containing granules (Rafacho et al., 2010) as well as higher insulin secretion in response to the PKC activator phorbol 12-myristate 13-acetate (PMA) (Rafacho et al., 2010). In addition, the cholinergic pathway, mediated by phospholipase C (PLC)/inositol triphosphate (IP3) / PKC signals, contributes to such an increase in $\beta$-cell function in GC-treated rats. The insulin secretion and $\left[\mathrm{Ca}^{2+}\right]_{\mathrm{i}}$ are increased in response to cholinergic stimulation in islets from GCtreated rats (Rafacho et al., 2008; Rafacho et al., 2010). It is known that DEX-treated rats exhibit higher islet content of muscarinic receptor type 3 (M3R) and PLC $\beta 1$. These islets are less responsive to cholinergic blockade during dynamic insulin secretion experiments in the presence of stimulatory concentrations of glucose and cholinergic agonists (Angelini et al., 2010). Corroborating this hypothesis, vagus dennervation partially abrogated the hyperinsulinemic profile in DEX-treated rats (Angelini et al., 2010). Notwithstanding the important role of glucose metabolism and cholinergic signals for the increased $\beta$-cell function in GC-treated rat models, the involvement of non-glucidic insulin secretagogues (amino acids and NEFA) (Novelli et al., 1999; Rafacho et al., 2010), non-metabolic signals (Rafacho et al., 2010), cyclic adenosine monophosphate (cAMP)-dependent protein kinases (Rafacho et al., 2010), and gap junctional intercellular communications (formed by connexin 36 protein in $\beta$-cells) (Rafacho et al., 2007) are also observed in these rats. All this information indicates that several factors are involved in augmentation of the insulin secretion response in islets isolated from GC-treated rats. It was recently demonstrated that insulin hypersecretion precedes any discernible indication of IR in DEX-treated rats (Rafacho et al., 2011). After 24 hours of DEX administration, rats become hyperinsulinemic and exhibit increased GSIS concomitant with normal blood glucose values, normal 
lipidemia, and without any evidence of IR. As the treatment continues, IR unfolds and islets become more responsive to glucose. A possible explanation for the early increase of insulin release may reside in central nervous system (CNS) signals. Direct administration of DEX to the CNS appears to increase parasympathetic system activity, resulting in augmented plasma insulin levels (Zakrzewska et al., 1999). This observation is in agreement with the results obtained with ganglionic antagonist infusion in DEX-induced IR and insulin hypersecretion in human volunteers as described before (Ahrén, 2008). Of note, all these altered ex vivo islet responses are transitory and reversible after discontinuation of GC treatment (Karlsson et al., 2001; Wierup et al., 2006; Rafacho et al., 2010); however, great caution is required in translating these observation to human applications.

\subsubsection{Structural changes in pancreatic islets in response to GC treatment in rats}

Compensatory islet hypertrophy in response to GC treatment in vivo was first described in the eighties (Jonas et al., 1983; Tomita et al., 1984; Zwicker \& Eyster, 1993). The mechanisms involved in islet hypertrophy were elucidated several years later (Rafacho et al., 2007; Rafacho et al., 2008; Rafacho et al., 2009). Activation of cell cycle progression machinery in normal rats in response to GC treatment is probably associated with the degree of IR that in turn is correlated to dose and/or duration of GC administration (Rafacho et al., 2009; Rafacho et al., 2011) and does not involve direct effects of GCs on $\beta$-cells, since it is known that steroids inhibit $\beta$-cell proliferation and promote $\beta$-cell death in vitro (Weinhaus et al., 2000; Liu et al., 2006; Ranta et al., 2006; Nicoletti-Carvalho et al., 2010). Instead, increased levels of circulating hormones and/or substrates, such as glucose, insulin, insulin-growth factor (IGF)-1, glucagon-like peptide (GLP)-1 and other circulating growth factors, may be responsible for promotion of $\beta$-cell growth in GC-treated rats [for review see references (Heit et al., 2006) and (Vasavada et al., 2006)]. $\beta$-cell proliferation is significantly increased after 5 days of DEX treatment in a positive reciprocity with steroid dose $(1.0 \mathrm{mg} / \mathrm{kg}>0.5$ $\mathrm{mg} / \mathrm{kg}$ b.w.), but absent when IR is modest as in 5 -days $0.1 \mathrm{mg} / \mathrm{kg}$ b.w. DEX treatment (Rafacho et al., 2009). The same correlation between IR degree and $\beta$-cell proliferation is observed when analyzed during time-course studies. After 1 day GC treatment, no changes in $\beta$-cell proliferation are observed and IR is not discernible. However, as GC treatment continues ( 3 to 5 days), IR develops and and the increase in $\beta$-cell proliferation is correlated with the degree of IR (Rafacho et al., 2011). With some combinations of GC treatment, $\beta$-cell hypertrophy is also observed (Choi et al., 2006; Rafacho et al., 2009). Thus, $\beta$-cell hypertrophy and/or proliferation accounts for increased $\beta$-cell mass upon GC treatment (Choi et al., 2006; Rafacho et al., 2010, Rafacho, 2009). This augmentation in $\beta$-cell mass is associated with increased islet protein content of insulin receptor substrate (IRS)-2, phosphorylated serinethreonine kinase (PKB), cyclin D (Cd)-2, cyclin-dependent kinase (Cdk)-4, phosphorylated retinoblastoma protein $(\mathrm{pRb})$, but not with activation of extracellular-regulated kinase (Erk)1/2 (Rafacho et al., 2008; Rafacho et al., 2009). Considering that plasma insulin concentrations increase in a GC dose- and/or time-dependent manner, it is conceivable that circulating insulin is one candidate mediator of $\beta$-cell growth. In addition, these GC-induced IR models do not 
exhibit changes in $\beta$-cell death (Rafacho et al., 2009; Rafacho et al., 2010) and almost all morphological changes are transitory and reversible after 10 days discontinuation of steroid treatment, suggesting an unacknowledged plasticity in the regulation of $\beta$-cell growth.

Taken altogether, like in humans, rats subjected to prolonged steroid treatment develop increased $\beta$-cell function as an adaptive compensation to surpass GC-induced IR. Susceptible strains; however, are prone to develop $\beta$-cell dysfunction that results in impaired glucose homeostasis. The $\beta$-cell growth accompanies the requirement for insulin in a direct relation with IR and demonstrates a great plasticity of endocrine pancreas to face fluctuations in metabolic demand.

\subsection{Functional and structural changes in pancreatic islets in GC-treated mice}

Less is known about in vivo GC effects in normal mice than in rats. Acute administration of hydrocortisone $(300 \mathrm{mg} / \mathrm{kg}$ b.w.) to male Swiss mice inhibits insulin secretion (Longano \& Fletcher, 1983) with reduced insulinogenic index already after $1 \mathrm{~h}$ of steroid administration. The insulin secretion in response to i.v. glucose load is also suppressed in this hydrocortisone model and may involve increased sympathetic drive. In response to prolonged DEX treatment ( $21 / 2$ days, with a dose equivalent to $1 \mathrm{mg} / \mathrm{kg}$ b.w.) islets isolated from normal adult mice show a modest decrease in insulin response to either $5.5 \mathrm{mM}$ or $16.7 \mathrm{mM}$ glucose. However, when the increment in insulin release between $5.5 \mathrm{mM}$ and $16.7 \mathrm{mM}$ glucose is calculated, a higher insulin response in DEX-treated animals as compared to vehicle treated mice is noted. As blood glucose and insulinemia were not determined in this experiment (Ling et al., 1998), which could indicate any deleterious GC effects on glucose homeostasis, caution should be exerted as to making conclusions about GC effects in normal mice.

Most of the data obtained with mouse models come from studies in genetically obese, leptin deficient mice $(o b / o b)$ that display IR (Table 3). Obese mice treated with $25 \mu \mathrm{g}$ DEX for 1 to $2 \frac{1}{2}$ days (at a dose equivalent to $0.5 \mathrm{mg} / \mathrm{kg}$ b.w.) exhibit increased islet glucose cycling (dephosphorylation of glucose-6-phosphate [G6P] to glucose by glucose-6-phosphatase [G6Pase]) both at $5.5 \mathrm{mM}$ and at $16.7 \mathrm{mM}$ glucose, but at the same time unaltered islet glucose oxidation and utilization. These results are associated with diminished or inhibited GSIS (Figure 2) (Khan et al., 1992; Khan et al., 1995). In an attempt to extrapolate these observations and determine whether they are caused by direct islet effects of GC in vivo, a transgenic mouse that overexpresses the GR specifically in $\beta$-cells was generated (Delaunay et al., 1997). These mice also displayed increased glucose cycling, mild glucose intolerance, decreased insulinogenic index and GSIS, but remained normoglycaemic (Delaunay et al., 1997; Ling et al., 1998). DEX treatment increased glucose cycling and the impairment of GSIS in this transgenic model. Again, islet glucose utilization and oxidation in the transgenic mice were comparable to those in control animals, demonstrating that the enhanced glucose flux trough G6Pase does not alter glucose utilization. Moreover, glucose cycling is neglible in normal rodents $(\approx 3 \%)$ and appears not to be a plausible explanation of the inhibitory effect of insulin release by DEX (Khan et al., 1992). The impact of direct GC effects in $\beta$-cells is better demonstrated in 11- to 12month-old transgenic mice (GR-overexpressing at $\beta$-cells). At this age, mice developed 
hyperglycemia and hypoinsulinemia, glucose intolerance, borderline IR (not significant), and decreased GSIS both in vivo and ex vivo. The reduction of GSIS was abolished after incubation of islets with an antagonist of $\alpha 2$-adrenergic receptor $(\alpha 2$-AdrR) that is associated with increased islet mRNA and $\alpha 2$-AdrR density. No alterations in GLUT2 distribution or in $\beta$-cell apoptosis were detected (Davani et al., 2004). Thus, the adrenergic signals (Figure 2) may participate in this impaired $\beta$-cell response caused by acutely or for more prolonged periods GC treatment. The transgenic approach revealed valuable information regarding the specific GC effects upon $\beta$-cells, but it does not take into account the overall metabolic GC effects. Studies conducted in adult mice treated with GCs, where peripheral effects of GCs are preserved, have shown increased circulating insulin levels when IR is apparent, but investigation of $\beta$-cell function and structure was not done (Thomas et al., 1998; Karatsoreos et al., 2010). In summary, acute GC treatment induces reduction of $\beta$-cell function in mice and this effect is accelerated in susceptible mice (old, obese or GR-overexpressing), which is in agreement with the deleterious effects of GCs on $\beta$-cell function known from studies with predisposed human individuals and in certain rat models. Nevertheless, GC effects on $\beta$-cell function and growth in normal mice are not known and merit further investigation.

\begin{tabular}{|c|c|c|c|c|c|c|c|}
\hline GC & $\mathbf{R}$ & Dosing & $\begin{array}{l}\text { Insulin } \\
\text { sensitivity (IS) } \\
\text { Glucose } \\
\text { tolerance (GT) }\end{array}$ & $\begin{array}{l}\text { Fasting } \\
\text { glycemia }\end{array}$ & $\begin{array}{l}\text { Fasting } \\
\text { insulinemia }\end{array}$ & $\begin{array}{l}\text { Insulin } \\
\text { secretion }\end{array}$ & Reference \\
\hline Dex & i.p. & $\begin{array}{l}1 \text { or } 2 \mathrm{~d} \text { of } 25 \mu \mathrm{g} \\
\text { for ob/ob mice } \\
\text { weighing around } \\
50 \mathrm{~g}\end{array}$ & ----- & $\begin{array}{l}\text { Unaltered in } \\
\text { both }\end{array}$ & $\begin{array}{l}\text { Unaltered in } 48 \\
\mathrm{~h} \text {, but not } \\
\text { determined } \\
\text { in } 24 \mathrm{~h}\end{array}$ & $\begin{array}{l}\text { Decreased } \\
(24 \mathrm{~h}) \text { or } \\
\text { inhibited } \\
(48 \mathrm{~h})\end{array}$ & $\begin{array}{l}\text { (Khan et } \\
\text { al., 1992) }\end{array}$ \\
\hline Dex & i.p. & $\begin{array}{l}21 / 2 \mathrm{~d} \text { of } 25 \mu \mathrm{g} \text { for } \\
\text { ob/ob mice } \\
\text { weighing more } \\
\text { than } 50 \mathrm{~g}\end{array}$ & ----- & ----- & ----- & ----- & $\begin{array}{l}\text { (Khan et } \\
\text { al., 1995) }\end{array}$ \\
\hline ----- & $\begin{array}{l}--- \\
-\end{array}$ & $\begin{array}{l}\text { Transgenic adult } \\
\text { mice }\end{array}$ & $\begin{array}{l}\text { Mild decrease } \\
\text { in GT }\end{array}$ & Unaltered & $\begin{array}{l}\text { Modest decrease } \\
\text { only in } 1 \text { from } 2 \\
\text { groups analyzed }\end{array}$ & Decreased & $\begin{array}{l}\text { (Delaunay } \\
\text { et al., 1997) }\end{array}$ \\
\hline Dex & i.p. & $\begin{array}{l}25 \mu \mathrm{g} \text { for } 21 / 2 \mathrm{~d} \text { in } \\
\text { normal or } \\
\text { transgenic adult } \\
\text { weighing around } \\
25 \mathrm{~g}\end{array}$ & ----- & $\begin{array}{l}\text { Unaltered } \\
\text { between } \\
\text { transgenic } \\
\text { and controls }\end{array}$ & ---- & $\begin{array}{l}\text { Decreased } \\
\text { in normal } \\
\text { and } \\
\text { transgenic }\end{array}$ & $\begin{array}{l}\text { (Ling et al., } \\
\text { 1998) }\end{array}$ \\
\hline ----- & - & $\begin{array}{l}12-15 \text { month-old } \\
\text { transgenic mice }\end{array}$ & $\begin{array}{l}\text { Tendency } \\
\text { towards } \\
\text { decrease in IS } \\
\text { Decreased GT }\end{array}$ & Increased & Decreased & Decreased & $\begin{array}{l}\text { (Davani et } \\
\text { al., 2004) }\end{array}$ \\
\hline
\end{tabular}

Table 3. Effects of prolonged GC treatment in $o b / o b$ or transgenic mice on endocrine pancreas parameters. 


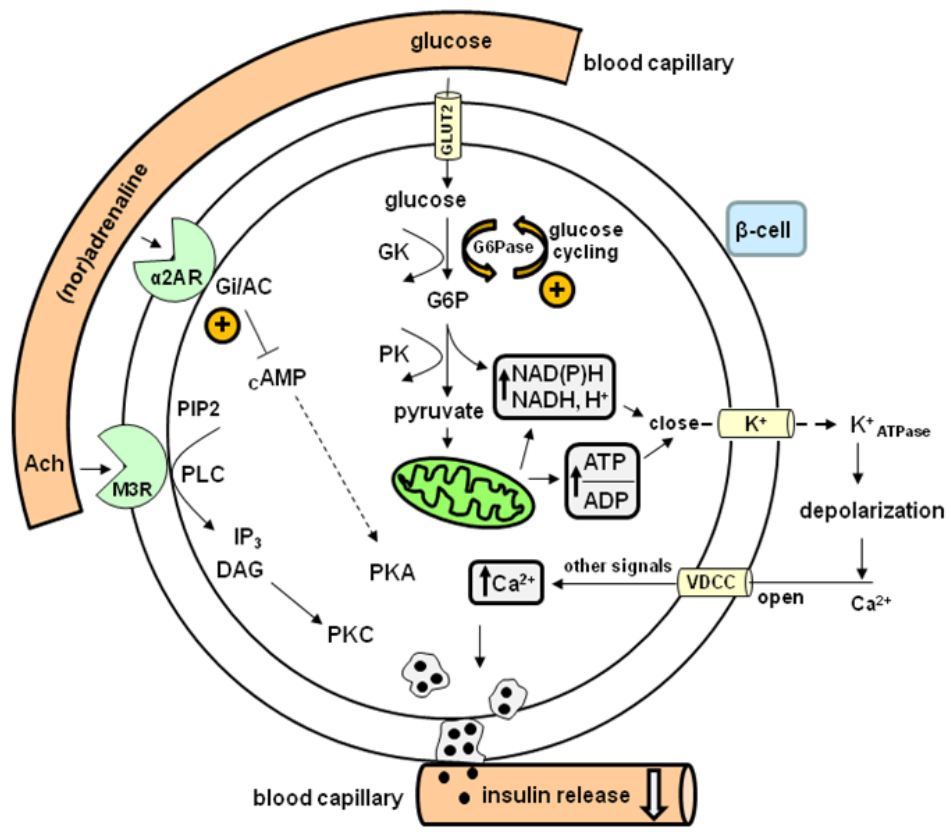

Figure 2. Insulin secretory process in $\beta$-cells from GC-treated mice. The known components involved in the reduced $\beta$-cell function are highlighted with a positive signal (orange circle), which indicates increased content or activity of the component after GC treatment. Most notably is the increased adrenergic activity that seems to inhibit insulin secretion. Abbreviations: AC, adenylyl cyclase; Ach, acetylcholine; ADP, adenosine diphosphate; ATP, adenosine trisphosphate; cAMP, cyclic adenosine monophosphate; DAG, diacylglycerol; G6P, glucose-6-phosphatase; Gi, G-coupled inhibitory protein; GK, glucokinase; GLUT2, glucose transporter 2; IP3, inositol trisphosphate; M3R, muscarinic receptor type 3; $\mathrm{NADH}$, nicotinamide dinucleotide; $\mathrm{NAD}(\mathrm{P}) \mathrm{H}$, nicotinamide adenonine dinucleotide phosphate; PIP2, phosphatidylinositol bisphosphate; PK, pyruvate kinase; PKA, protein kinase A; PKC, protein kinase C; PLC, phospholipase C; VDCC, voltage-dependent calcium channel. Modified from Nussey \& Whitehead, 2001; Endocrinology: An integrated approach, box 2.19 (Nussey \& Whitehead, 2001).

\subsection{Direct glucocorticoid effects on insulin secretion and $\beta$-cell growth in islets and $\beta$-cell lines}

In vitro, as in vivo, it is difficult to determine with accuracy the specific factors involved in the GC effects on $\beta$-cell function. This is because in vitro culture does not mimic perfectly the metabolic milieu of an intact system in vivo. For example, the timing, duration and level of exposure to GC compounds, the concentration range of serum and/or glucose in the culture medium, the concentration and variety of insulin secretagogues chosen, and the $\beta$ cell (isolated islets, dispersed islet $\beta$-cells, $\beta$-cell lines) and species (human, hamster, rat or mouse islets) vary (Santerre et al., 1981; Lambillotte et al., 1997; Myrsén-Axcrona et al., 1997; Fabregat et al., 1999; Jeong et al., 2001; Shao et al., 2004; Arumugam et al., 2008; Swali et al., 2008; Roma et al., 2011). Despite the repercussions of these variables, in vitro insights have been of great importance to elucidate the direct effects of GCs on insulin secretion. 


\subsubsection{Acute GC effects}

Rodent-derived islets or dispersed $\beta$-cells have diminished or inhibited insulin response to non-metabolizable and metabolizable secretagogues, especially to glucose, both after acute (minutes) (Billaudel \& Sutter, 1979; Barseghian \& Levine, 1980) or prolonged (hours to days) GC exposure (Lambillotte et al., 1997; Weinhaus et al., 2000; Jeong et al., 2001; Zawalich et al., 2006). In the presence of three different concentrations (physiological and supraphysiological), corticosterone does not affect rat islet insulin secretion under basal glucose conditions, whereas, in response to $16.7 \mathrm{mM}$ glucose, insulin release is inhibited. This study emphasizes that physiological corticosterone concentrations $(0.02$ and $0.2 \mathrm{mg} / \mathrm{L})$ have strong negative impact on insulin secretion (Billaudel \& Sutter, 1979). In the same trend, it was shown that cathecolaminergic signals may play a role in this process, since phentolamine, an $\alpha$-AdrR blocking agent, ameliorated the strong inhibitory effect of corticosterone on insulin release (Barseghian \& Levine, 1980). This immediate negative effect of corticosterone on insulin release is not reproduced by the synthetic GC DEX in isolated mouse (Lambillotte et al., 1997) or rat islets (Zawalich et al., 2006). Thus, acute GC effects on insulin release appear to be more evident with natural corticosterone used at physiological concentrations.

\subsubsection{Hours to days GC effects}

The inhibition of insulin secretion by GCs begins after 3 to 6 hours (Lambillotte et al., 1997; Weinhaus et al., 2000; Zawalich et al., 2006). The mechanisms by which this occurs are not completely understood, but several components are already identified as shown in a schematic overview and the proposed loci of interference by GCs in Figure 3. Details regarding GC compounds used, concentrations, duration of treatment, and main effects on $\beta$-cell function are described in Table 4. The GC-induced reduction in GSIS could not be attributed to decreases in insulin content since it was unchanged or augmented (Pierluissi et al., 1986; Gremlich et al., 1997; Lambillotte et al., 1997; Zawalich et al., 2006), although reduction was also observed under certain conditions (Jeong et al., 2001). It has been shown that presence of DEX in islet or $\beta$-cell culture medium induces reduction (Gremlich et al., 1997) or no change (Shao et al., 2004) in GLUT 2 protein content, decrease in $\beta$-cell GK (Shao et al., 2004) and pyruvate dehydrogenase (PDH) (Arumugam et al., 2010) activities, and increased pyruvate dehydrogenase kinase (PDK)-2 mRNA content (Arumugam et al., 2010). Despite alterations of these proximal metabolic components, the failure of $\beta$-cells' response to glucose does not appear to involve a defect in the recognition of glucose, because no changes in the rate of glucose oxidation (Lambillotte et al., 1997; Zawalich et al., 2006), oxygen consumption (Ortsäter et al., 2005), NAD(P)H production (Lambillotte et al., 1997), or $\left[\mathrm{Ca}^{2+}\right]_{i}$ (Lambillotte et al., 1997) have been observed. There are controversies related to $\mathrm{Ca}^{2+}$ influx in response to glucose or non-glucidic stimuli (Myrsén-Axcrona et al., 1997; Koizumi \& Yada, 2008), but in spite of elevation or reduction in $\mathrm{Ca}^{2+}$ influx, there is consensus that $\mathrm{Ca}^{2+}$ oscillations are impaired, which may harm the distal events of secretion dependent of finely tuned $\mathrm{Ca}^{2+}$ handling. 


\begin{tabular}{|c|c|c|c|}
\hline$\overline{\mathrm{GC}}$ & $\begin{array}{l}\text { Dose and period, and } \beta \text {-cell } \\
\text { source }\end{array}$ & Main results & Reference \\
\hline Cort & $\begin{array}{l}0.02,0.2 \text { or } 20 \mathrm{mg} / 1 \text { along } \\
\text { first min in isolated rat islets }\end{array}$ & $\begin{array}{l}\text { With } 4.2 \mathrm{mM} \text { glucose, Cort did not affect IS, but with } \\
16.7 \mathrm{mM} \text { glucose IS was inhibited by the three Cort } \\
\text { concentrations tested during static incubation, and } \\
\text { by the two physiological during islets perifusion }\end{array}$ & $\begin{array}{l}\text { (Billaudel \& } \\
\text { Sutter, 1979) }\end{array}$ \\
\hline Cort & $\begin{array}{l}\text { Physiological Cort } \\
\text { concentrations along first in } \\
\text { rat pancreas }\end{array}$ & $\begin{array}{l}\text { Acutely inhibit the IS induced by both glucose and } \\
\text { arginine. Phentolamine, an } \alpha \text {-adrenergic blocking } \\
\text { agent, diminished the strong inhibitory effect of Cort } \\
\text { on IS }\end{array}$ & $\begin{array}{l}\text { (Barseghian } \\
\text { \& Levine, } \\
\text { 1980) }\end{array}$ \\
\hline Dex & $\begin{array}{l}0.1-1.0 \mu \mathrm{M} \text { for } 6,48 \text { or } 96 \mathrm{~h} \\
\text { in hamster } \beta \text {-cell line (HIT) }\end{array}$ & $\begin{array}{l}\text { Inhibited the IS to the culture medium after } 48 \text { or } 96 \\
h \text {, but not to } 6 \mathrm{~h}\end{array}$ & $\begin{array}{l}\text { (Santerre et } \\
\text { al., 1981) }\end{array}$ \\
\hline Hydr & $\begin{array}{l}0.063,0.63 \text { or } 6.3 \mu \mathrm{M} \text { for } 1,2 \\
\text { or } 3 \mathrm{~h} \text { in rat islets }\end{array}$ & $\begin{array}{l}\text { No alteration at } 2 \mathrm{mM} \text { glucose, but reduced GSIS ( } 20 \\
\mathrm{mM} \text { ) when cultured with } 6.3 \mu \mathrm{M} \text { Dex for } 1,2 \text { or } 3 \mathrm{~h} \\
\text { or } 2 \mathrm{~h} \text { with } 0.063 \mu \mathrm{M} \text { or } 630 \mu \mathrm{M} \text { for islet culture. The } \\
\text { reduced GSIS under } 6.3 \mu \mathrm{M} \text { for } 2 \mathrm{~h} \text { culture was also } \\
\text { seen with } 7.5,10,12.5,15,20 \text { and } 30 \mathrm{mM} \text { glucose. } \\
\text { These responses were re-established after } 4 \mathrm{~h} \text {. Pred } \\
\text { and Hydr also induced decreased GSIS and none of } \\
\text { these drugs elicit a decrease in islet insulin content }\end{array}$ & $\begin{array}{l}\text { (Pierluissi et } \\
\text { al., 1986) }\end{array}$ \\
\hline $\begin{array}{l}\text { Dex } \\
\text { Pred } \\
\text { Hydr }\end{array}$ & $\begin{array}{l}24 \mathrm{~h} \text { in HIT-T15 or RIN-5AH } \\
\text { cells }\end{array}$ & $\begin{array}{l}\text { Dex, Pred and Hydr induced an increase of } \alpha 2 \text {-AdrR } \\
\text { in HIT cells that was prevented by the GR antagonist } \\
\text { RU38486. } 1 \mu \mathrm{M} \text { Dex also induced increased } \\
\text { expression of receptor in RIN- } 5 \text { cells }\end{array}$ & $\begin{array}{l}\text { (Hamamdzic } \\
\text { et al., 1995) }\end{array}$ \\
\hline Dex & $1 \mu \mathrm{M}$ for $18 \mathrm{~h}$ in mouse islets & $\begin{array}{l}\text { Dex had inhibitory effect from the } 3^{\text {rd }} \mathrm{h} \text { incubation. } \\
\text { Cultured islets in presence of Dex } 1 \mu \mathrm{M} \text { had higher } \\
\text { insulin content than control and the reversibility of } \\
\text { GSIS in islets treated with } 0.25 \mu \mathrm{M} \text { dex was observed } \\
\text { after } 3 \mathrm{~h} \text { of DEX discontinuation. } 20 \mathrm{mM} \text { glucose in } \\
\text { the medium or the presence of KIC did not change } \\
\text { the inhibitory effect of Dex; however, PMA, cAMP } \\
\text { or inhibition of } \alpha 2 \text {-AdrR was able to attenuate or } \\
\text { reversed the negative action of } 18 \mathrm{~h} 1 \mu \mathrm{M} \text { Dex. The } \\
\text { presence of pertussis toxin abolished the negative } \\
\text { effect of Dex. IS continues inhibited even after } \\
\text { stimulation with tolbutamide, high glucose and } \\
\text { diazoxide. Glucose oxidation and NAD(P)H were } \\
\text { similar between both islet groups in presence of } 3 \text { or } \\
15 \text { mM glucose. Dex islets had reduced response } \\
\text { under high glucose during the dynamic protocol and } \\
\text { the pattern of calcium oscillations were changed in } \\
\text { Dex islets. IS and calcium influx were also lower in } \\
\text { response to Cch in Dex islets }\end{array}$ & $\begin{array}{l}\text { (Lambillotte } \\
\text { et al., 1997) }\end{array}$ \\
\hline Dex & $1 \mu \mathrm{M}$ for $48 \mathrm{~h}$ in rat islets & $\begin{array}{l}\text { Dex induced a decrease in GLUT2 protein } \\
\text { expression in a glucose-dependent manner that is } \\
\text { blunted by RU } 486 \text {. Addition of palmitic acid had no } \\
\text { additive effect on the reduction of GLUT2 protein }\end{array}$ & $\begin{array}{l}\text { (Gremlich et } \\
\text { al., 1997) }\end{array}$ \\
\hline
\end{tabular}




\begin{tabular}{|c|c|c|c|}
\hline \multirow[t]{2}{*}{ GC } & $\begin{array}{l}\text { Dose and period, and } \beta \text {-cell } \\
\text { source }\end{array}$ & Main results & Reference \\
\hline & & $\begin{array}{l}\text { expression compared to Dex alone. Dex induced an } \\
\text { inhibition of GSIS that was also evidenced by } \\
\text { palmitic acid alone or in combination with Dex. The } \\
\text { total islet insulin content were decreased in response } \\
\text { to the palmitic acid whereas were increased by Dex. } \\
\text { The effect of Dex was inhibited by RU486 }\end{array}$ & \\
\hline Dex & $\begin{array}{l}100 \mathrm{nM} \text { for } 1 \text { to } 5 \mathrm{~d} \text { in } \\
\text { RINm } 5 \text { cells }\end{array}$ & $\begin{array}{l}\text { Dex induced an increase in NPY mRNA expression } \\
\text { in a time-dependent manner. It also induced an } \\
\text { increase in NPY immunoreactivity. Dex treated cells } \\
\text { had less IS to the medium, whereas increased NPY } \\
\text { release. IS in several conditions was reduced in cells } \\
\text { treated with Dex. The D-glyceraldehyde-induced } \\
\left.\text { raise in [Ca }{ }^{2+}\right] \text { was impaired after Dex treatment. } \\
\text { Also, the increase in cytosolic calcium when } \\
\text { stimulated with } \mathrm{KCl} \text { was lowered by Dex. }\end{array}$ & $\begin{array}{l}\text { (Myrsén- } \\
\text { Axcrona et } \\
\text { al., 1997) }\end{array}$ \\
\hline Dex & $\begin{array}{l}1 \mathrm{nM}-1 \mu \mathrm{M} \text { during } 6 \mathrm{~d} \\
\text { culture in } 5 \mathrm{~d} \text { neonate rat } \\
\text { islets }\end{array}$ & $\begin{array}{l}\text { After } 6 \mathrm{~d} \text { culture, } 10 \mathrm{nM} \text { to } 1 \mu \mathrm{M} \text { Dex markedly } \\
\text { reduced the content of IS to the medium in control } \\
\text { and in PRL-treated islets. Dex }(100 \mathrm{nM}) \text { exerted its } \\
\text { effects since the } 1^{\text {st }} \text { day culture and abolished the } \\
\text { positive effects of PRL when incubated together with } \\
\text { PRL. Six d of } 100 \mathrm{nM} \text { Dex inhibited the IS from } 2.8 \text { to } \\
7.2 \text { or } 13.5 \mathrm{mM} \text { glucose alone or in combination with } \\
\text { PRL, but did not induce a decrease in total islet } \\
\text { insulin content }\end{array}$ & $\begin{array}{l}\text { (Weinhaus et } \\
\text { al., 2000) }\end{array}$ \\
\hline $\begin{array}{l}11- \\
\text { DHC }\end{array}$ & $\begin{array}{l}50 \text { or } 500 \mathrm{nM} 11-\mathrm{DHC} \text { for } 20 \\
\mathrm{~h} \text { in ob/ob mouse islets }\end{array}$ & $\begin{array}{l}\text { Incubation of } \beta \text { cells in the presence of 11-DHC led } \\
\text { to a dose-dependent inhibition of IS. Inhibition of } \\
11 \beta \text {-HSD1 activity by carbenoxolone reversed } \\
\text { inhibition of IS }\end{array}$ & $\begin{array}{l}\text { (Davani et } \\
\text { al., 2004) }\end{array}$ \\
\hline Dex & $\begin{array}{l}1,10 \text { or } 100 \mathrm{nM} \text { for } 1 \text { to } 6 \mathrm{~h} \\
\text { in rat islets }\end{array}$ & $\begin{array}{l}\text { IS decreased in a time- and dose-dependent manner } \\
\text { being significant already after the } 1^{\text {st }} \mathrm{h} \text { incubation } \\
\text { within } 10 \text { or } 100 \mathrm{nM} \text { Dex, but not for } 1 \mathrm{nM} \text { until the } \\
6^{\text {th }} \mathrm{h} \text { culture. The } 1^{\text {st }} \text {, but not } 2^{\text {nd }} \text { phase GSIS were } \\
\text { reduced in response to } 10 \text { or } 100 \mathrm{nM} \text { Dex (Dex were } \\
\text { exposed only during perifusion). The islet insulin } \\
\text { content was higher in islets from } 1,10 \text { and } 100 \mathrm{nM} \\
\text { culture after } 1 \mathrm{~h} \text { treatment and reduced for only } 100 \\
\mathrm{nM} \text { after } 6 \mathrm{~h} \text {. After } 6 \text {, but not } 1 \mathrm{~h}, 10 \text { and } 100 \mathrm{nM} \text { Dex } \\
\text { reduced the pre-proinsulin mRNA content. }\end{array}$ & $\begin{array}{l}\text { (Jeong et al., } \\
\text { 2001) }\end{array}$ \\
\hline Dex & $\begin{array}{l}50 \mathrm{ng} / \mathrm{ml}-1 \mathrm{ug} / \mathrm{ml} \text { for } 24 \mathrm{~h} \text { in } \\
\text { MIN6 cells }\end{array}$ & $\begin{array}{l}\text { Dex from } 50 \mathrm{ng} \text { to } 1 \mathrm{mg} / \mathrm{ml} \text { inhibited IS to the culture } \\
\text { medium after } 24 \mathrm{~h} \text {. Dex ( } 100 \mathrm{nM} \text { ) inhibited GSIS in a } \\
\text { time-dependent fashion from the } 6 \mathrm{~h} \text { to } 48 \mathrm{~h} \\
\text { treatment. Dex (100nM) did not change GK protein } \\
\text { content, but inhibited GK activity from the } 6 \mathrm{~h} \text { ahead } \\
\text { and did not affect the GLUT2 protein content during } \\
\text { long term treatments. Even in response to KIC Dex- } \\
\text { treated cells had inhibited IS. Dex induces a }\end{array}$ & $\begin{array}{l}\text { (Shao et al., } \\
\text { 2004) }\end{array}$ \\
\hline
\end{tabular}




\begin{tabular}{|c|c|c|c|}
\hline \multirow[t]{2}{*}{ GC } & $\begin{array}{l}\text { Dose and period, and } \beta \text {-cell } \\
\text { source }\end{array}$ & Main results & Reference \\
\hline & & $\begin{array}{l}\text { reduction in cAMP content that was prevented by } \\
\text { the presence of the inhibitor of the PDE. The increase } \\
\text { in PDE activity was confirmed after Dex treatment }\end{array}$ & \\
\hline Dex & $\begin{array}{l}100 \mathrm{nM} \text { for } 4 \mathrm{~h} \text { in mouse } \\
\text { islets or INS1 cells. For IHC, } \\
\text { mice received } 1 \text { injection of } \\
10 \mathrm{mg} / \mathrm{kg} \text { b.w. Dex and } \\
\text { killed } 24 \mathrm{~h} \text { after }\end{array}$ & $\begin{array}{l}\text { After } 4 \mathrm{~h} 100 \mathrm{nM} \text { Dex it was observed increased } \\
\text { mRNA expression of Kv-1.5 (repolarizing K } \\
\text { channel). This was associated with increased SGK1 } \\
\text { mRNA and protein expression in a time-dependent } \\
\text { manner (INS1 cells) and immunoreactivity in mice } \\
\text { islet pancreas. All analysis in cells was abrogated by } \\
\text { the presence of RU } 486 \text {. The activity of Kv-1.5 channel } \\
\text { was increased after Dex treatment and mediated by } \\
\left.\text { SGK1, that was associated to reduced [Ca }{ }^{2+}\right] \text { i peaks in } \\
\text { response to glucose. The inhibited GSIS in DEX- } \\
\text { treated INS1 cells and mouse islets were reverted by } \\
\text { the presence of K channel inhibitors TEA and MSD. } \\
\text { Presence of diazoxide and high KCL also reversed } \\
\text { the insulin secretion in DEX-treated INS1 cells. SGK1 } \\
\text { knockout mice did not present the same reduction in } \\
\text { GSIS. }\end{array}$ & $\begin{array}{l}\text { (Ullrich et al., } \\
\text { 2005) }\end{array}$ \\
\hline $\begin{array}{l}\text { 11- } \\
\text { DHC }\end{array}$ & $\begin{array}{l}5,50 \text { or } 500 \mathrm{nM} 11-\mathrm{DHC} \text { for } \\
48 \mathrm{~h} \text { in } o b / o b \text { mouse islets }\end{array}$ & $\begin{array}{l}\text { Islets from the ob/ob mouse contained almost } \\
\text { twofold more } 11 \beta \text {-HSD1 protein than islets from the } \\
\text { C57BL/6J mouse. When islets from ob/ob mice were } \\
\text { cultured with } 50 \mathrm{nM} 11 \text {-DHC, the } 11 \beta \text {-HSD1 levels } \\
\text { doubled compared with islets cultured in the } \\
\text { absence of DHC. Selective inhibition of } 11 \beta \text {-HSD1 } \\
\text { attenuated DHC-induced increase in } 11 \beta \text {-HSD1 } \\
\text { levels, as did an antagonist of the GR. In } \\
\text { individually perfused ob/ob mouse islets, early and } \\
\text { late phases of GSIS were dose-dependently inhibited } \\
\text { by } 11-D H C \text {. Whereas inclusion of } 11 \beta \text {-HSD1 } \\
\text { inhibitors restored, addition of the GR antagonist } \\
\text { attenuated the DHC-mediated inhibition of GSIS. }\end{array}$ & $\begin{array}{l}\text { (Ortsäter et } \\
\text { al., 2005) }\end{array}$ \\
\hline Dex & $\begin{array}{l}100 \mathrm{nM} \text { for } 3 \mathrm{~d} \text { in BRIN-BD } \\
11 \text { cells }\end{array}$ & $\begin{array}{l}\text { DEX-treated cells lacked responsiveness to glucose } \\
\text { and membrane depolarisation, and both PKA and } \\
\text { PKC secretory pathways were desensitised. }\end{array}$ & $\begin{array}{l}\text { (Liu et al., } \\
\text { 2006) }\end{array}$ \\
\hline Dex & $\begin{array}{l}1 \mu \mathrm{M} \text { concomitant or for } 3 \mathrm{~h} \\
\text { previous culture in rat islets }\end{array}$ & $\begin{array}{l}\text { Dex (included in the perifusion solution) has no } \\
\text { effect on GSIS. Previous incubation with Dex } \\
\text { markedly decrease the } 1^{\text {st }} \text { and the } 2^{\text {nd }} \text { phases IS } \\
\text { under } 15 \mathrm{mM} \text { glucose. This result was not associated } \\
\text { to reduction in insulin content or glucose oxidation. } \\
\text { IS was also reduced in response to TPA or } \mathrm{KCl} \text { in } \\
\text { Dex islets. Dex also reduces the agonist-induced } \\
\text { inositol phosphate accumulation in islets, but did } \\
\text { not change the protein content of } 5 \text { different PLC } \\
\text { protein isoforms. Significant reductions in glucose- } \\
\text { induced IP accumulation accompanied the reduction }\end{array}$ & $\begin{array}{l}\text { (Zawalich et } \\
\text { al., 2006) }\end{array}$ \\
\hline
\end{tabular}




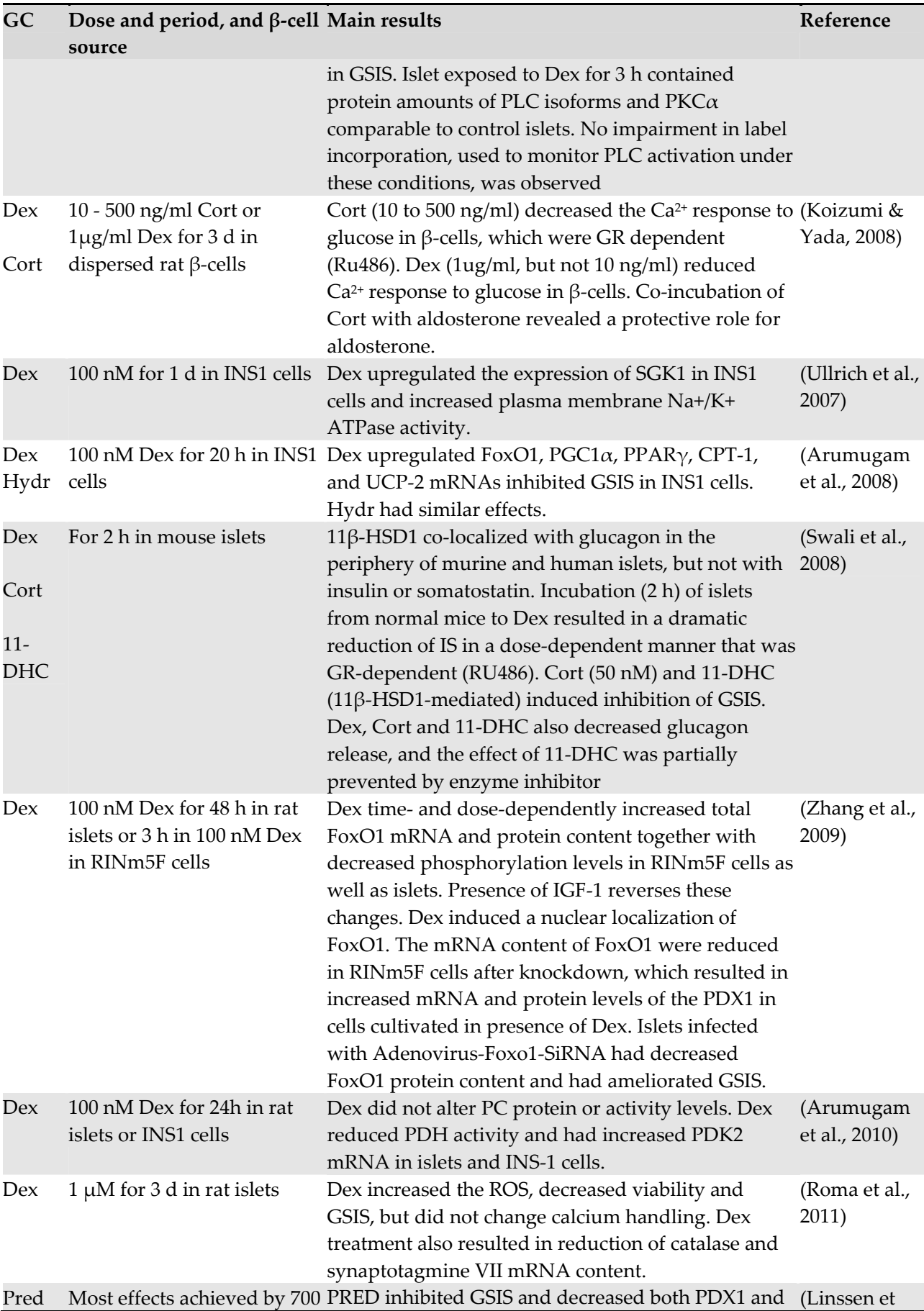




\begin{tabular}{|c|c|c|c|}
\hline GC & $\begin{array}{l}\text { Dose and period, and } \beta \text {-cell } \\
\text { source }\end{array}$ & Main results & Reference \\
\hline & $\mathrm{nM}$ after $20 \mathrm{~h}$ in INS1 cells & $\begin{array}{l}\text { insulin expression, leading to a marked reduction in } \\
\text { cellular insulin content. These PRED-induced } \\
\text { detrimental effects were GR-mediated (RU486). } \\
\text { PRED induced a GR-mediated activation of both } \\
\text { ATF6 and IRE1/XBP1 pathways but was found to } \\
\text { reduce the phosphorylation of PERK and its } \\
\text { downstream substrate eIF2 } \alpha \text {. These modulations of } \\
\text { ER stress pathways were accompanied by } \\
\text { upregulation of calpain } 10 \text {, increased cleaved } \\
\text { caspase } 3 \text { and } \beta \text {-cell apoptosis. }\end{array}$ & al., 2011) \\
\hline
\end{tabular}

Dex; dexamethasone, Pred; prednisolone, Cort; corticosterone, GSIS; glucose-stimulated insulin secretion, Hydr; hydrocorticosterone, IS; insulin secretion, 11-DHC; 11-hydroxysteroid dehydrogenase

Table 4. Effects of GCs in vitro on insulin secretion from islets, dispersed islet $\beta$-cells or $\beta$-cell lines.

The insulin secretory dysfunction induced by GCs is not solely restricted to glucose. Additional effects may contribute to $\beta$-cell dysfunction; impairment of insulin secretion in response to $\alpha$-ketoisocaproate (KIC), tolbutamide, or high $\mathrm{K}^{+}$concentration after DEX treatment is also observed (Lambillotte et al., 1997; Shao et al., 2004; Liu et al., 2006), suggesting that factors distal to oxidative phosphorylation (KIC) or metabolismindependent signals (tolbutamide, high $\mathrm{K}^{+}$) may also be involved in the adverse GC effects on the insulin secretory process. DEX may also modulate the inward repolarizing $\mathrm{K}^{+}$ currents by upregulating $\mathrm{K}_{\mathrm{v}} 1.5$ ion channels as well as $\mathrm{Na}^{+} / \mathrm{K}^{+}$ATPase activity, which appear to be mediated through activation of the serum- and GC-inducible kinase (SGK1)-1 (Ullrich et al., 2005; Ullrich et al., 2007). These repolarizing currents may limit $\mathrm{Ca}^{2+}$ influx and insulin secretion. Downstream steps in the insulin secretory machinery also seem involved in the direct GC derangements in $\beta$-cells. Zawalich and colleagues (Zawalich et al., 2006) demonstrated that DEX pretreatment of rat islets impairs insulin secretion by decreasing activation of the PLC/PKC signaling pathway. Moreover, GCs increase the mRNA content and $\alpha$-2AdrR protein density in $\beta$-cell lines (Hamamdzic et al., 1995), which may explain the lower cyclic adenosine monophosphate (cAMP) levels and attenuated GSIS (Shao et al., 2004). This latter event is prevented by phosphodiesterase (PDE) inhibitors, which aligns well with the upregulated PDE activity by DEX treatment (Shao et al., 2004), although controversy remains (Lambillotte et al., 1997). Overall, it appears that GCs act at distal sites by diminishing the efficacy of $\left[\mathrm{Ca}^{2+}\right]$ i on the secretory response by interfering with the amplifying pathway, although we cannot exclude their possible negative effects also in the mechanisms involved in the rapid first phase insulin secretion (Jeong et al., 2001). The interference of GCs in distal sites of the insulin secretory machinery may explain the wide spectrum of non-glucose insulin secretagogues being inhibited by GCs (Lambillotte et al., 1997; Myrsén-Axcrona et al., 1997; Shao et al., 2004; Liu et al., 2006).

\subsubsection{Recent insights into GC effects on insulin secretion in vitro.}

The mRNA content of Forkhead box O (FoxO)-1, peroxisome proliferator activator receptor (PPAR) $-\gamma$ coactivator (PGC)-1 $\alpha$ and uncoupling protein (UCP)-2 were upregulated in 
primary islets after 20 hours of DEX treatment (Arumugam et al., 2008). From these observations, it is expected that GC-induced derangements of GSIS can include limited production of cellular ATP due to UCP-2 mediated uncoupling of oxidative phosphorylation. In addition, increased PGC1- $\alpha$ action, which is associated with elevated fat acid oxidation, could induce impairments in insulin secretory process mediated by lack of critical lipid mediators involved in the amplifying pathway (Herrero et al., 2005). The GCinduced increment in total FoxO1 mRNA and protein content, as well as decreased levels of FoxO-1 phosphorylation in a rat insulinoma cell line (RINm5F), are time-and dosedependent effects and appear to be mediated by the IGF-1 pathway (Zhang et al., 2009). Using molecular tools, it was demonstrated that lack of FoxO-1 ameliorates the DEXinduced impairment of GSIS in $\beta$-cell lines, an effect associated with increased levels of pancreatic duodenal homeobox (PDX)-1. It was recently demonstrated that presence of $1 \mu \mathrm{M}$ DEX for 3 consecutive days in primary islet culture results in increased generation of reactive oxygen species (ROS) (Roma et al., 2011). This study also revealed impaired generation of $\mathrm{NAD}(\mathrm{P}) \mathrm{H}$ and reduced GSIS, decreased gene expression of catalase (an antioxidant enzyme) and synaptotagmin VII, without alteration in $\mathrm{Ca}^{2+}$ handling. These DEX effects were attenuated by N-acetylcysteine (NAC) (Roma et al., 2011), further supporting a role for ROS in mediating the cytotoxic effects of GCs. The role of endoplasmic reticulum (ER) homeostasis has also been investigated in the context of prednisolone-induced $\beta$-cell dysfunction. It has been observed that PDX-1 expression and cellular insulin content are reduced by steroid treatment (700 $\mathrm{nM}$ for 20 hours) in INS-1E cells, which resulted in inhibition of GSIS (Linssen et al., 2011). Prednisolone exerts its effects by activation of activating transcription factor (ATF)-6 and inositol requiring enzyme (IRE)-1/X-box binding protein (XBP)-1 pathways and by decreasing the phosphorylation of protein kinase RNA-activated (PKR)-like eukaryotic initiation factor $2 \alpha$ kinase (PERK) and its downstream substrate eukaryotic initiation (eIF2)- $\alpha$. Thus, $\beta$-cell dysfunction induced by GCs may be, at least partially, attributed to ER dyshomeostasis. These mechanisms are depicted in Figure 3.

\subsubsection{1ß-hydroxysteroid dehydrogenase type 1 and pancreatic islets}

The enzyme $11 \beta$-hydroxysteroid dehydrogenase type 1 (11 $\beta$-HSD1) catalyzes the conversion of inactive 11-dehydrocorsticosterone (11-DHC) to active corticosterone in rodents and it was found in pancreatic islets isolated from ob/ob mice and humans (Davani et al., 2000). Incubation of $\beta$-cells in the presence of 11-DHC leads to a dose-dependent attenuation of GSIS, indicating that cellular activation of 11-DHC may play a role in GC-induced $\beta$-cell dysfunction and that $11 \beta$-HSD1 may potentiate the detrimental effect of GCs on $\beta$-cell function. The protein content of $11 \beta-H S D 1$ is higher in islets from $o b / o b$ mice, compared to C57BL/6J mice, and is further increased when $o b / o b$ islets are cultured in presence of 11-DHC (Ortsäter et al., 2005). GSIS in islets from ob/ob mice (but not from normal mice) was dosedependently inhibited in presence of 11-DHC, an effect prevented by addition of selective 11ß-HSD1 inhibitors or GR antagonist RU486 (Ortsäter et al., 2005). Recently, it was demonstrated that $11 \beta$-HSD1 is mainly localized to pancreatic $\alpha$-cells both in mouse and human islets (Swali et al., 2008). In that study, mouse islets had lower glucagon or insulin secretion when cultured in presence of DEX, corticosterone or 11-DHC; the effect of 11-DHC 
was partially prevented by an 11 $\beta$-HSD1 inhibitor. These data suggest that the ability of $\alpha-$ cells to generate active GC within the islet impacts on insulin and glucagon secretion by three distinct mechanisms: (1) directly at the level of the $\alpha$-cells, modulating glucagon secretion; (2) by decreasing glucagon secretion, which may decrease insulin secretion via glucagon receptors expressed on the $\beta$-cells and (3) by GC production by $\alpha$-cells acting in a paracrine manner, regulating insulin secretion from neighbouring $\beta$-cells (Swali et al., 2008). Although the overall conclusion of these findings is that $11 \beta$-HSD1 plays a negative role in pancreatic $\beta$-cell function, it should be noted that the complete lack of $11 \beta$-HSD1 expression in $\beta$-cells is associated with mild $\beta$-cell impairment (Turban et al., 2012). In addition, moderate $\beta$-cell specific overexpression of $11 \beta$-HSD1 can protect against the diabetogenic effects of a high-fat diet. These data lend support to the notion that GCs under certain conditions can promote $\beta$-cell function (Hult et al., 2009; Rafacho et al., 2010).

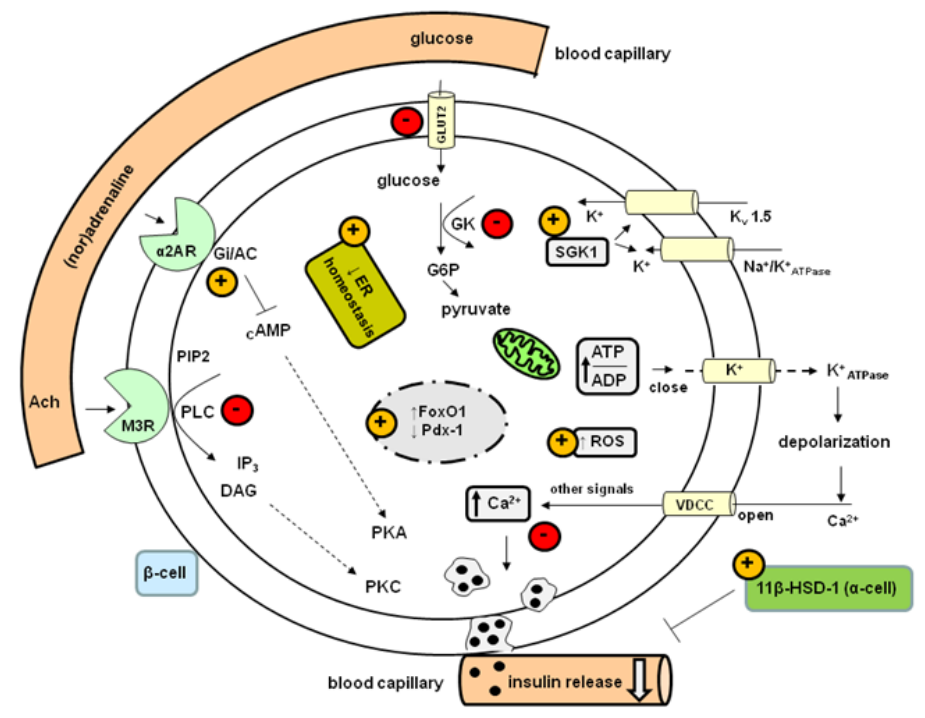

Figure 3. Direct GC effects on the insulin secretory process in $\beta$-cells. The known components involved in the direct effects of GCs on the $\beta$-cell insulin secretory process are highlighted with a positive signal (orange circle - indicates GCs stimulate that action) or negative signal (red circle - indicates GCs inhibit that action). Most notably, GCs impair $\beta$-cell glucose metabolism, favor repolarizing $\mathrm{K}^{+}$currents, decrease PKA and PKC activation, induce ER dyshomeostasis and increased FoxO1 protein content that altogether impair calcium handling and inhibits insulin secretion. Abbreviations: AC, adenylyl cyclase; Ach, acetylcholine; ADP, adenosine diphosphate; ATP, adenosine trisphosphate; cAMP, cyclic adenosine monophosphate; Cx36, connexin 36; DAG, diacylglycerol; ER, endoplasmic reticulum; FFA, free fatty acids; FoxO1, Forkhead box O; G6P, glucose-6-phosphatase; Gs, G-coupled stimulatory protein; GK, glucokinase; GLUT2, glucose transporter 2; IP3, inositol trisphosphate; $\mathrm{K}_{\mathrm{v} 15}$, voltage-dependent $\mathrm{K}^{+}$channel; M3R, muscarinic receptor type 3; PDX-1, pancreatic duodenal homeobox; PIP2, phosphatidylinositol bisphosphate; PKA, protein kinase A; PKC, protein kinase C; PLC, phospholipase C; SGK-1, serum- and glucocorticoid inducible kinase-1; VDCC, voltage-dependent calcium channel, 11- $\beta$ HSD-1, 11- $\beta$ hydroxysteroid dehydrogenase type 1. Modified from Nussey \& Whitehead, 2001; Endocrinology: An integrated approach, box 2.19 (Nussey \& Whitehead, 2001) and from van Raalte et al., 2009; Eur J Clin Invest 2009, 39(2):page 87, Figure 3 (van Raalte et al., 2009). 


\subsubsection{Effects of GCs on $\beta$-cell growth in vitro}

It was demonstrated in the seventies that $10 \mu \mathrm{g} / \mathrm{ml} \mathrm{DEX}$ exerts inhibitory effects on $\beta$-cell proliferation in rat pancreatic monolayer cells (Chick, 1973). Several years later, it was found that $100 \mathrm{nM}$ DEX negatively interferes with the positive effects of prolactin on $\beta$-cell growth both in mouse islet cells and INS-1 cells (Weinhaus et al., 2000). The direct effects of DEX on $\beta$-cell proliferation and $\beta$-cell death are GR-mediated and involve the activation of caspase3, mitochondrial depolarization, reduction of $\mathrm{Bcl}-2$ protein content, increase of Hsp90 protein, increased calcineurin activity with attendant elevation in dephosphorylated BAD protein levels, and inhibition of IRS-2, PKB and ERK phosphorylations (Ranta et al., 2006; Avram et al., 2008; Ranta et al., 2008). Exendin-4, an agonist of GLP-1 receptor, and IGF-1 protect $\beta$-cells against DEX-induced $\beta$-cell death. In a recent study, specific knockdown of mitogen-activated protein kinase (MAPK) phosphatase (MKP)-1 in RINm5F and MIN6 insulinoma cells, counteracted the down-regulation of ERK1/2 protein phosphorylation and the reduction of $\beta$-cell proliferation induced by DEX (Nicoletti-Carvalho et al., 2010). Prednisolone also induces $\beta$-cell apoptosis in INS-1E cells through up-regulation of calpain 10 and increased cleavage of caspase- 3 (Linssen et al., 2011). In their entirety, these data, summarized in Table 5, clearly demonstrate the negative effects of GCs on $\beta$-cell growth that contrasts to those observed when GCs are administered in vivo.

\begin{tabular}{|c|c|c|c|}
\hline$\overline{\mathrm{GC}}$ & $\begin{array}{l}\text { Dose and period, and } \beta \text { - } \\
\text { cell source }\end{array}$ & Main results & Reference \\
\hline Dex & $\begin{array}{l}10 \mu \mathrm{g} / \mathrm{ml} \text { for } 4 \mathrm{~d} \text { in rat } \\
\text { pancreatic monolayer cells }\end{array}$ & Reduced $\beta$-cell proliferation & $\begin{array}{l}\text { (Chick, } \\
\text { 1973) }\end{array}$ \\
\hline Dex & $\begin{array}{l}100 \mathrm{nM} \text { for } 24 \mathrm{~h} \text { to } 3 \mathrm{~d} \text { in } \\
\text { rat islet }\end{array}$ & $\begin{array}{l}\text { Dex alone did not induce significant decrease in } \beta \text {-cell } \\
\text { proliferation, but markedly decreased the positive effect of } \\
\text { PRL on } \beta \text {-cell proliferation. Dex for } 24 \mathrm{~h} \text { to } 3 \mathrm{~d} \text { induced an } \\
\text { increase in islet cell death even in the presence of PRL. }\end{array}$ & $\begin{array}{l}\text { (Weinhau } \\
\text { s et al., } \\
\text { 2000) }\end{array}$ \\
\hline Dex & $\begin{array}{l}100 \mathrm{nM} \text { for } 1 \text { or } 4 \mathrm{~d} \text { in } \\
\text { mouse } \beta \text {-cells or INS1 cells }\end{array}$ & $\begin{array}{l}\text { Dex induced mouse islet cells or INS1 cells death that was } \\
\text { GR-dependent (RU486). Dex induced caspase } 3 \text { activity in } \\
\text { INS1 cells. Dex reduced mRNA and protein content of Bcl-2 } \\
\text { and decrease of mitochondrial polarization. Dex-induced } \\
\text { cell death was associated to increased calcineurin activity } \\
\text { and increased BAD dephosphorylation (all reverted by } \\
\text { RU486 or calcineurin inhibitors). Exendin-4 protects islet } \\
\text { cells and INS1 cells from Dex-induced cell death via } \\
\text { activation of PKA. }\end{array}$ & $\begin{array}{l}\text { (Ranta et } \\
\text { al., 2006) }\end{array}$ \\
\hline Dex & $\begin{array}{l}100 \mathrm{nM} \text { for } 1 \mathrm{~d} \text { in INS-1 } \\
\text { cells }\end{array}$ & \multicolumn{2}{|c|}{$\begin{array}{l}\text { Dex inhibited cell growth, BrdU incorporation and induced (Avram et } \\
\text { apoptosis. Dex induced cell death was partially antagonizedal., 2008) } \\
\text { by IGF-1. Despite increased IRS-2 protein, IRS-2 tyrosine } \\
\text { phosphorylation stimulated by IGF-1 was inhibited by Dex. } \\
\text { Dex treatment reduced basal PKB phosphorylation. } \\
\text { However, IGF-1-mediated ERK phosphorylation was } \\
\text { affected. }\end{array}$} \\
\hline Dex & $\begin{array}{l}100 \mathrm{nM} \text { for } 1 \text { to } 4 \mathrm{~d} \text { in INS- } \\
1 \text { cells }\end{array}$ & \multicolumn{2}{|c|}{$\begin{array}{l}\text { In INS- } 1 \text { cells cultured up to } 4 \mathrm{~d} \text { with Dex, the percentage of (Ranta et } \\
\text { apoptosis increased from } 1 \% \text { to } 10.9 \% \text {. FK506 inhibited dex-al., 2008) }\end{array}$} \\
\hline
\end{tabular}




\begin{tabular}{|c|c|c|c|}
\hline \multirow[t]{2}{*}{ GC } & $\begin{array}{l}\text { Dose and period, and } \beta \text { - } \\
\text { cell source }\end{array}$ & Main results & Reference \\
\hline & & $\begin{array}{l}\text { mediated cell death. Apoptosis was significantly higher at } \\
\text { glucose concentrations that induce }\left[\mathrm{Ca}^{2+}\right] \text { i oscillations than } \\
\text { at low, non-stimulatory glucose. Calcineurin activity was } \\
\text { unaltered after Dex treatment. However, Dex treatment } \\
\text { significantly increased enzyme activity at submaximal, } \\
\text { physiological Ca }{ }^{2+} \text { concentrations. Dex did not stimulate the } \\
\mathrm{Ca}^{2+} \text {-dependent protease calpain, known to activate } \\
\text { calcineurin by cleavage. In Dex-treated cells Hsp90 protein, } \\
\text { a component of the GR known to stimulate calcineurin,was } \\
\text { increased while calcineurin protein levels were unchanged. } \\
\text { In immunoprecipitates with calcineurin antibodies, Hsp90 } \\
\text { was only detected in Dex-treated cell homogenates. }\end{array}$ & \\
\hline Dex & $\begin{array}{l}\text { 100nM Dex for } 3 \mathrm{~d} \text { culture } \\
\text { both for MIN6 or Rin } 5 \text { cells }\end{array}$ & $\begin{array}{l}\text { Dex reduced phospho-ERK } 1 / 2 \text { and increased MKP-1 } \\
\text { expression in RINm5F and MIN- } 6 \text { cells. Inhibition of } \\
\text { transduction with cycloheximide and inhibition of } \\
\text { phosphatases with orthovanadate efficiently blocked DEX- } \\
\text { induced downregulation of phospho-ERK1/2. In addition, } \\
\text { specific knockdown of MKP-1 with siRNA suppressed the } \\
\text { downregulation of phospho-ERK1/2 and the reduction of } \\
\text { proliferation induced by DEX. }\end{array}$ & $\begin{array}{l}\text { (Nicoletti- } \\
\text { Carvalho } \\
\text { et al., } \\
2010 \text { ) }\end{array}$ \\
\hline
\end{tabular}

Table 5. Effects of GC in vitro on cell growth in islets, dispersed islet $\beta$-cells or $\beta$-cell lines.

\section{Conclusions}

Collectively, direct effects of GCs on $\beta$-cell function in vitro are opposite to those observed when the GCs are administered in vivo to healthy individuals (especially humans and rats), which does not exclude that in vivo GCs might exert their known negative effects on $\beta$-cells, e.g. by increasing $11 \beta$-HSD1 activity, induce apoptosis and eventually obscure glucose sensing. However, based on data summarized herein, it seems clear that these direct effects of steroids on the $\beta$-cells are overwhelmed by the compensatory adaptations provoked by the GC-induced IR in vivo. Whether continuation of GC treatment for long periods (weeks to years) in healthy individuals results in impaired $\beta$-cell function is still a matter of debate; nevertheless, it is reasonable to say that since short treatments in susceptible subjects (obese, low-insulin responders, first-degree relatives of patients with T2DM, pregnant, etc) clearly demonstrate $\beta$-cell dysfunction, great caution should be exerted as to use GC therapies in high doses and/or with prolonged duration. The direct effects of GCs are achieved through classical ligand-GR mechanisms, since selective inhibition of GR prevents most GC-induced impairments of $\beta$-cells in vitro (Hamamdzic et al., 1995; Gremlich et al., 1997; Lambillotte et al., 1997; Ullrich et al., 2005; Ranta et al., 2006; Koizumi \& Yada, 2008; Swali et al., 2008; Linssen et al., 2011) and in vivo (Ohneda et al., 1993). The extent of non-genomic actions of GCs on insulin secretion is not yet clear. However, rapid effects observed by physiological GC concentrations seem to involve sympathetic autonomic signals (Longano \& Fletcher, 
1983), whereas synthetic compounds with GC activity do not elicit acute modifications in $\beta$ cell responses to insulin secretagogues (Lambillotte et al., 1997; Zawalich et al., 2006). The real involvement of $11 \beta$-HSD1 on pancreatic islets milieu as well as the effects of GCs on pancreatic $\alpha$-cells and its paracrine consequences on pancreatic $\beta$-cell function remain to be investigated.

\section{Author details}

Alex Rafacho

Department of Physiological Sciences, Centre of Biological Sciences, Universidade Federal de Santa Catarina, Brazil

Antonio C. Boschero

Department of Structural and Functional Biology, Universidade Estadual de Campinas, Brazil

Henrik Ortsäter

Department of Clinical Science and Education, Södersjukhuset, Karolinska Insititutet, Sweden

\section{Acknowledgement}

H. Ortsäter is funded by the Swedish Society for Medical Research. A. C. Boschero is funded by FAPESP and CNPq. A. Rafacho is funded by CNPq and FAPESC. The authors have no conflict of interest to disclose.

\section{References}

Ahrén, B. (2008). Evidence that autonomic mechanisms contribute to the adaptive increase in insulin secretion during dexamethasone-induced insulin resistance in humans. Diabetologia Vol. 51, No. 6, pp. 1018-1024

Andrews, R.C., \& Walker, B.R. (1999). Glucocorticoids and insulin resistance: old hormones, new targets. Clin Sci (Lond) Vol. 96, No. 5, pp. 513-523

Angelini, N., Rafacho, A., Boschero, A.C., \& Bosqueiro, J.R. (2010). Involvement of the cholinergic pathway in glucocorticoid-induced hyperinsulinemia in rats. Diabetes Res Clin Pract Vol. 87, No. 2, pp. 184-191

Arumugam, R., Horowitz, E., Lu, D., Collier, J.J., Ronnebaum, S., Fleenor, D., \& Freemark, M. (2008). The interplay of prolactin and the glucocorticoids in the regulation of betacell gene expression, fatty acid oxidation, and glucose-stimulated insulin secretion: implications for carbohydrate metabolism in pregnancy. Endocrinology Vol. 149, No. 11, pp. 5401-5414

Arumugam, R., Horowitz, E., Noland, R.C., Lu, D., Fleenor, D., \& Freemark, M. (2010). Regulation of islet beta-cell pyruvate metabolism: interactions of prolactin, glucose, and dexamethasone. Endocrinology Vol. 151, No. 7, pp. 3074-3083

Avram, D., Ranta, F., Hennige, A.M., Berchtold, S., Hopp, S., Haring, H.U., Lang, F., \& Ullrich, S. (2008). IGF-1 protects against dexamethasone-induced cell death in insulin 
secreting INS-1 cells independent of AKT/PKB phosphorylation. Cell Physiol Biochem Vol. 21, No. 5-6, pp. 455-462

Barbera, M., Fierabracci, V., Novelli, M., Bombara, M., Masiello, P., Bergamini, E., \& De Tata, V. (2001). Dexamethasone-induced insulin resistance and pancreatic adaptive response in aging rats are not modified by oral vanadyl sulfate treatment. Eur J Endocrinol Vol. 145, No. 6, pp. 799-806

Barseghian, G., \& Levine, R. (1980). Effect of corticosterone on insulin and glucagon secretion by the isolated perfused rat pancreas. Endocrinology Vol. 106, No. 2, pp. 547552

Beard, J.C., Halter, J.B., Best, J.D., Pfeifer, M.A., \& Porte, D., Jr. (1984). Dexamethasoneinduced insulin resistance enhances $B$ cell responsiveness to glucose level in normal men. Am J Physiol Vol. 247, No. 5 Pt 1, pp. E592-596

Besse, C., Nicod, N., \& Tappy, L. (2005). Changes in insulin secretion and glucose metabolism induced by dexamethasone in lean and obese females. Obes Res Vol. 13, No. 2, pp. 306-311

Billaudel, B., \& Sutter, B.C. (1979). Direct effect of corticosterone upon insulin secretion studied by three different techniques. Horm Metab Res Vol. 11, No. 10, pp. 555-560

Binnert, C., Ruchat, S., Nicod, N., \& Tappy, L. (2004). Dexamethasone-induced insulin resistance shows no gender difference in healthy humans. Diabetes Metab Vol. 30, No. 4, pp. 321-326

Borelli, M.I., Garcia, M.E., Gomez Dumm, C.L., \& Gagliardino, J.J. (1982). Glucocorticoidinduced changes in insulin secretion related to the metabolism and ultrastructure of pancreatic islets. Horm Metab Res Vol. 14, No. 6, pp. 287-292

Chick, W.L. (1973). Beta cell replication in rat pancreatic monolayer cultures. Effects of glucose, tolbutamide, glucocorticoid, growth hormone and glucagon. Diabetes Vol. 22, No. 9, pp. 687-693

Choi, S.B., Jang, J.S., Hong, S.M., Jun, D.W., \& Park, S. (2006). Exercise and dexamethasone oppositely modulate beta-cell function and survival via independent pathways in $90 \%$ pancreatectomized rats. J Endocrinol Vol. 190, No. 2, pp. 471-482

Chuthaputti, A., \& Fletcher, H.P. (1987). Effect of hydrocortisone on terbutaline stimulated insulin release from isolated pancreatic islets. Res Commun Chem Pathol Pharmacol Vol. 57, No. 3, pp. 329-341

Davani, B., Khan, A., Hult, M., Martensson, E., Okret, S., Efendic, S., Jornvall, H., \& Oppermann, U.C. (2000). Type 1 11 $\beta$-hydroxysteroid dehydrogenase mediates glucocorticoid activation and insulin release in pancreatic islets. J Biol Chem Vol. 275, No. 45, pp. 34841-34844.

Davani, B., Portwood, N., Bryzgalova, G., Reimer, M.K., Heiden, T., Ostenson, C.G., Okret, S., Ahren, B., Efendic, S., \& Khan, A. (2004). Aged transgenic mice with increased glucocorticoid sensitivity in pancreatic beta-cells develop diabetes. Diabetes Vol. 53 Suppl 1, No., pp. S51-59

Delaunay, F., Khan, A., Cintra, A., Davani, B., Ling, Z.C., Andersson, A., Ostenson, C.G., Gustafsson, J., Efendic, S., \& Okret, S. (1997). Pancreatic $\beta$ cells are important targets for the diabetogenic effects of glucocorticoids. J Clin Invest Vol. 100, No. 8, pp. 2094-2098 
Dessein, P.H., \& Joffe, B.I. (2006). Insulin resistance and impaired beta cell function in rheumatoid arthritis. Arthritis Rheum Vol. 54, No. 9, pp. 2765-2775

Fabregat, M.E., Fernandez-Alvarez, J., Franco, C., Malaisse, W.J., \& Gomis, R. (1999). Dexamethasone-induced changes in FAD-glycerophosphate dehydrogenase mRNA, content and activity, and insulin release in human pancreatic islets. Diabetes Nutr Metab Vol. 12, No. 6, pp. 388-393

Giozzet, V.A., Rafacho, A., Boschero, A.C., Carneiro, E.M., \& Bosqueiro, J.R. (2008). Dexamethasone treatment in vivo counteracts the functional pancreatic islet alterations caused by malnourishment in rats. Metabolism Vol. 57, No. 5, pp. 617-624

Gremlich, S., Roduit, R., \& Thorens, B. (1997). Dexamethasone induces posttranslational degradation of GLUT2 and inhibition of insulin secretion in isolated pancreatic $\beta$ cells. Comparison with the effects of fatty acids. J Biol Chem Vol. 272, No. 6, pp. 3216-3222.

Grill, V., Pigon, J., Hartling, S.G., Binder, C., \& Efendic, S. (1990). Effects of dexamethasone on glucose-induced insulin and proinsulin release in low and high insulin responders. Metabolism Vol. 39, No. 3, pp. 251-258

Hamamdzic, D., Duzic, E., Sherlock, J.D., \& Lanier, S.M. (1995). Regulation of alpha 2adrenergic receptor expression and signaling in pancreatic beta-cells. Am J Physiol Vol. 269, No. 1 Pt 1, pp. E162-171

Heit, J.J., Karnik, S.K., \& Kim, S.K. (2006). Intrinsic regulators of pancreatic $\beta$-cell proliferation. Annu Rev Cell Dev Biol Vol. 22, No., pp. 311-338

Henriksen, J.E., Alford, F., Ward, G.M., \& Beck-Nielsen, H. (1997). Risk and mechanism of dexamethasone-induced deterioration of glucose tolerance in non-diabetic first-degree relatives of NIDDM patients. Diabetologia Vol. 40, No. 12, pp. 1439-1448

Herrero, L., Rubi, B., Sebastian, D., Serra, D., Asins, G., Maechler, P., Prentki, M., \& Hegardt, F.G. (2005). Alteration of the Malonyl-CoA/Carnitine Palmitoyltransferase I Interaction in the $\beta$-Cell Impairs Glucose-Induced Insulin Secretion. Diabetes Vol. 54, No. 2, pp. $462-$ 471

Hollingdal, M., Juhl, C.B., Dall, R., Sturis, J., Veldhuis, J.D., Schmitz, O., \& Porksen, N. (2002). Glucocorticoid induced insulin resistance impairs basal but not glucose entrained high-frequency insulin pulsatility in humans. Diabetologia Vol. 45, No. 1, pp. 49-55

Holness, M.J., Smith, N.D., Greenwood, G.K., \& Sugden, M.C. (2005). Interactive influences of peroxisome proliferator-activated receptor alpha activation and glucocorticoids on pancreatic beta cell compensation in insulin resistance induced by dietary saturated fat in the rat. Diabetologia Vol. 48, No. 10, pp. 2062-2068

Holness, M.J., \& Sugden, M.C. (2001). Dexamethasone during late gestation exacerbates peripheral insulin resistance and selectively targets glucose-sensitive functions in beta cell and liver. Endocrinology Vol. 142, No. 9, pp. 3742-3748

Hult, M., Ortsäter, H., Schuster, G., Graedler, F., Beckers, J., Adamski, J., Ploner, A., Jornvall, H., Bergsten, P., \& Oppermann, U. (2009). Short-term glucocorticoid treatment increases insulin secretion in islets derived from lean mice through multiple pathways and mechanisms. Mol Cell Endocrinol Vol. 301, No. 1-2, pp. 109-116 
Jeong, I.K., Oh, S.H., Kim, B.J., Chung, J.H., Min, Y.K., Lee, M.S., Lee, M.K., \& Kim, K.W. (2001). The effects of dexamethasone on insulin release and biosynthesis are dependent on the dose and duration of treatment. Diabetes Res Clin Pract Vol. 51, No. 3, pp. 163-171.

Jonas, L., Putzke, H.P., \& Hahn von Dorsche, H. (1983). The islands of Langerhans in rats (Rattus norvegicus, Forma alba) following administration of prednisolone - semiquantitative light and electron microscopy study. Anat Anz Vol. 154, No. 4, pp. 273-282

Kahn, S.E., Prigeon, R.L., McCulloch, D.K., Boyko, E.J., Bergman, R.N., Schwartz, M.W., Neifing, J.L., Ward, W.K., Beard, J.C., Palmer, J.P., \& et al. (1993). Quantification of the relationship between insulin sensitivity and beta-cell function in human subjects. Evidence for a hyperbolic function. Diabetes Vol. 42, No. 11, pp. 1663-1672

Kalhan, S.C., \& Adam, P.A. (1975). Inhibitory effect of prednisone on insulin secretion in man: model for duplication of blood glucose concentration. J Clin Endocrinol Metab Vol. 41, No. 3, pp. 600-610

Karatsoreos, I.N., Bhagat, S.M., Bowles, N.P., Weil, Z.M., Pfaff, D.W., \& McEwen, B.S. (2010). Endocrine and physiological changes in response to chronic corticosterone: a potential model of the metabolic syndrome in mouse. Endocrinology Vol. 151, No. 5, pp. 2117-2127

Karlsson, S., Ostlund, B., Myrsen-Axcrona, U., Sundler, F., \& Ahren, B. (2001). Beta cell adaptation to dexamethasone-induced insulin resistance in rats involves increased glucose responsiveness but not glucose effectiveness. Pancreas Vol. 22, No. 2, pp. 148156

Kautzky-Willer, A., Thomaseth, K., Clodi, M., Ludvik, B., Waldhausl, W., Prager, R., \& Pacini, G. (1996). Beta-cell activity and hepatic insulin extraction following dexamethasone administration in healthy subjects. Metabolism Vol. 45, No. 4, pp. 486491

Khan, A., Hong-Lie, C., \& Landau, B.R. (1995). Glucose-6-phosphatase activity in islets from $\mathrm{ob} / \mathrm{ob}$ and lean mice and the effect of dexamethasone. Endocrinology Vol. 136, No. 5, pp. 1934-1938

Khan, A., Ostenson, C.G., Berggren, P.O., \& Efendic, S. (1992). Glucocorticoid increases glucose cycling and inhibits insulin release in pancreatic islets of ob/ob mice. Am J Physiol Vol. 263, No. 4 Pt 1, pp. E663-666

Koizumi, M., \& Yada, T. (2008). Sub-chronic stimulation of glucocorticoid receptor impairs and mineralocorticoid receptor protects cytosolic $\mathrm{Ca} 2+$ responses to glucose in pancreatic beta-cells. J Endocrinol Vol. 197, No. 2, pp. 221-229

Koranyi, L., Bourey, R., Turk, J., Mueckler, M., \& Permutt, M.A. (1992). Differential expression of rat pancreatic islet beta-cell glucose transporter (GLUT 2), proinsulin and islet amyloid polypeptide genes after prolonged fasting, insulin-induced hypoglycaemia and dexamethasone treatment. Diabetologia Vol. 35, No. 12, pp. 11251132

Lambillotte, C., Gilon, P., \& Henquin, J.C. (1997). Direct glucocorticoid inhibition of insulin secretion. An in vitro study of dexamethasone effects in mouse islets. J Clin Invest Vol. 99, No. 3, pp. 414-423.

Larsson, H., \& Ahren, B. (1999). Insulin resistant subjects lack islet adaptation to short-term dexamethasone-induced reduction in insulin sensitivity. Diabetologia Vol. 42, No. 8, pp. 936-943 
Lee, H.C., Bonner-Weir, S., Weir, G.C., \& Leahy, J.L. (1989). Compensatory adaption to partial pancreatectomy in the rat. Endocrinology Vol. 124, No. 3, pp. 1571-1575

Ling, Z.C., Khan, A., Delauny, F., Davani, B., Ostenson, C.G., Gustafsson, J.A., Okret, S., Landau, B.R., \& Efendic, S. (1998). Increased glucocorticoid sensitivity in islet beta-cells: effects on glucose 6-phosphatase, glucose cycling and insulin release. Diabetologia Vol. 41, No. 6, pp. 634-639.

Linssen, M.M., van Raalte, D.H., Toonen, E.J., Alkema, W., van der Zon, G.C., Dokter, W.H., Diamant, M., Guigas, B., \& Ouwens, D.M. (2011). Prednisolone-induced beta cell dysfunction is associated with impaired endoplasmic reticulum homeostasis in INS-1E cells. Cell Signal Vol. 23, No. 11, pp. 1708-1715

Liu, H.K., Green, B.D., McClenaghan, N.H., McCluskey, J.T., \& Flatt, P.R. (2006). Deleterious effects of supplementation with dehydroepiandrosterone sulphate or dexamethasone on rat insulin-secreting cells under in vitro culture condition. Biosci Rep Vol. 26, No. 1, pp. 31-38

Longano, C.A., \& Fletcher, H.P. (1983). Insulin release after acute hydrocortisone treatment in mice. Metabolism Vol. 32, No. 6, pp. 603-608

Matschinsky, F. (1996). A lesson in metabolic regulation inspired by the glucokinase glucose sensor paradigm. Diabetes Vol. 45, No., pp. 223-241

Myrsén-Axcrona, U., Karlsson, S., Sundler, F., \& Ahren, B. (1997). Dexamethasone induces neuropeptide $\mathrm{Y}$ (NPY) expression and impairs insulin release in the insulin-producing cell line RINm5F. Release of NPY and insulin through different pathways. J Biol Chem Vol. 272, No. 16, pp. 10790-10796

Nesher, R., Anteby, E., Yedovizky, M., Warwar, N., Kaiser, N., \& Cerasi, E. (2002). Beta-cell protein kinases and the dynamics of the insulin response to glucose. Diabetes Vol. 51 Suppl 1, No., pp. S68-73

Nicod, N., Giusti, V., Besse, C., \& Tappy, L. (2003). Metabolic adaptations to dexamethasone-induced insulin resistance in healthy volunteers. Obes Res Vol. 11, No. 5, pp. 625-631

Nicoletti-Carvalho, J.E., Lellis-Santos, C., Yamanaka, T.S., Nogueira, T.C., Caperuto, L.C., Leite, A.R., Anhe, G.F., \& Bordin, S. (2010). MKP-1 mediates glucocorticoid-induced ERK1/2 dephosphorylation and reduction in pancreatic ss-cell proliferation in islets from early lactating mothers. Am J Physiol Endocrinol Metab Vol. 299, No. 6, pp. E10061015

Novelli, M., De Tata, V., Bombara, M., Lorenzini, A., Masini, M., Pollera, M., Bergamini, E., \& Masiello, P. (1999). Insufficient adaptive capability of pancreatic endocrine function in dexamethasone-treated ageing rats. J Endocrinol Vol. 162, No. 3, pp. 425-432

Novelli, M., Pocai, A., Chiellini, C., Maffei, M., \& Masiello, P. (2008). Free fatty acids as mediators of adaptive compensatory responses to insulin resistance in dexamethasonetreated rats. Diabetes Metab Res Rev Vol. 24, No. 2, pp. 155-164

Nussey, S., \& Whitehead, S. (2001). Endocrinology: An Integrated Approach. Oxford, BIOS Scientific Publishers Limited.

O'Brien, T.D., Westermark, P., \& Johnson, K.H. (1991). Islet amyloid polypeptide and insulin secretion from isolated perfused pancreas of fed, fasted, glucose-treated, and dexamethasone-treated rats. Diabetes Vol. 40, No. 12, pp. 1701-1706 
Ogawa, A., Johnson, J.H., Ohneda, M., McAllister, C.T., Inman, L., Alam, T., \& Unger, R.H. (1992). Roles of insulin resistance and $\beta$-cell dysfunction in dexamethasone-induced diabetes. J Clin Invest Vol. 90, No. 2, pp. 497-504

Ohneda, M., Johnson, J.H., Inman, L.R., \& Unger, R.H. (1993). GLUT-2 function in glucoseunresponsive $\beta$-cells of dexamethasone-induced diabetes in rats. J Clin Invest Vol. 92, No. 4, pp. 1950-1956

Ortsäter, H., Alberts, P., Warpman, U., Engblom, L.O., Abrahmsén, L., \& Bergsten, P. (2005). Regulation of $11 \beta$-hydroxysteroid dehydrogenase type 1 and glucose-stimulated insulin secretion in pancreatic islets of Langerhans. Diabetes Metab Res Rev Vol. 21, No. 4, pp. 359-366

Pagano, G., Cavallo-Perin, P., Cassader, M., Bruno, A., Ozzello, A., Masciola, P., Dall'omo, A.M., \& Imbimbo, B. (1983). An in vivo and in vitro study of the mechanism of prednisone-induced insulin resistance in healthy subjects. J Clin Invest Vol. 72, No. 5, pp. $1814-1820$

Pierluissi, J., Navas, F.O., \& Ashcroft, S.J. (1986). Effect of adrenal steroids on insulin release from cultured rat islets of Langerhans. Diabetologia Vol. 29, No. 2, pp. 119-121

Qi, D., Pulinilkunnil, T., An, D., Ghosh, S., Abrahani, A., Pospisilik, J.A., Brownsey, R., Wambolt, R., Allard, M., \& Rodrigues, B. (2004). Single-dose dexamethasone induces whole-body insulin resistance and alters both cardiac fatty acid and carbohydrate metabolism. Diabetes Vol. 53, No. 7, pp. 1790-1797

Rafacho, A., Abrantes, J.L., Ribeiro, D.L., Paula, F.M., Pinto, M.E., Boschero, A.C., \& Bosqueiro, J.R. (2011). Morphofunctional alterations in endocrine pancreas of short- and long-term dexamethasone-treated rats. Horm Metab Res Vol. 43, No. 4, pp. 275-281

Rafacho, A., Cestari, T.M., Taboga, S.R., Boschero, A.C., \& Bosqueiro, J.R. (2009). High doses of dexamethasone induce increased $\beta$-cell proliferation in pancreatic rat islets. Am J Physiol Endocrinol Metab Vol. 296, No. 4, pp. E681-689

Rafacho, A., Giozzet, V.A., Boschero, A.C., \& Bosqueiro, J.R. (2008). Functional alterations in endocrine pancreas of rats with different degrees of dexamethasone-induced insulin resistance. Pancreas Vol. 36, No. 3, pp. 284-293

Rafacho, A., Marroqui, L., Taboga, S.R., Abrantes, J.L., Silveira, L.R., Boschero, A.C., Carneiro, E.M., Bosqueiro, J.R., Nadal, A., \& Quesada, I. (2010). Glucocorticoids in vivo induce both insulin hypersecretion and enhanced glucose sensitivity of stimulussecretion coupling in isolated rat islets. Endocrinology Vol. 151, No. 1, pp. 85-95

Rafacho, A., Quallio, S., Ribeiro, D.L., Taboga, S.R., Paula, F.M., Boschero, A.C., \& Bosqueiro, J.R. (2010). The adaptive compensations in endocrine pancreas from glucocorticoid-treated rats are reversible after the interruption of treatment. Acta Physiol (Oxf) Vol. 200, No. 3, pp. 223-235

Rafacho, A., Ribeiro, D.L., Boschero, A.C., Taboga, S.R., \& Bosqueiro, J.R. (2008). Increased pancreatic islet mass is accompanied by activation of the insulin receptor substrate2/serine-threonine kinase pathway and augmented cyclin D2 protein levels in insulinresistant rats. Int J Exp Pathol Vol. 89, No. 4, pp. 264-275

Rafacho, A., Roma, L.P., Taboga, S.R., Boschero, A.C., \& Bosqueiro, J.R. (2007). Dexamethasone-induced insulin resistance is associated with increased connexin 36 
mRNA and protein expression in pancreatic rat islets. Can J Physiol Pharmacol Vol. 85, No. 5, pp. 536-545

Ranta, F., Avram, D., Berchtold, S., Dufer, M., Drews, G., Lang, F., \& Ullrich, S. (2006). Dexamethasone induces cell death in insulin-secreting cells, an effect reversed by exendin-4. Diabetes Vol. 55, No. 5, pp. 1380-1390

Ranta, F., Dufer, M., Stork, B., Wesselborg, S., Drews, G., Haring, H.U., Lang, F., \& Ullrich, S. (2008). Regulation of calcineurin activity in insulin-secreting cells: stimulation by Hsp90 during glucocorticoid-induced apoptosis. Cell Signal Vol. 20, No. 10, pp. 1780-1786

Roma, L.P., Oliveira, C.A., Carneiro, E.M., Albuquerque, G.G., Boschero, A.C., \& Souza, K.L. (2011). N-acetylcysteine protects pancreatic islet against glucocorticoid toxicity. Redox Rep Vol. 16, No. 4, pp. 173-180

Santerre, R.F., Cook, R.A., Crisel, R.M., Sharp, J.D., Schmidt, R.J., Williams, D.C., \& Wilson, C.P. (1981). Insulin synthesis in a clonal cell line of simian virus 40-transformed hamster pancreatic beta cells. Proc Natl Acad Sci U S A Vol. 78, No. 7, pp. 4339-4343

Schneiter, P., \& Tappy, L. (1998). Kinetics of dexamethasone-induced alterations of glucose metabolism in healthy humans. Am J Physiol Vol. 275, No. 5 Pt 1, pp. E806-813

Severino, C., Brizzi, P., Solinas, A., Secchi, G., Maioli, M., \& Tonolo, G. (2002). Low-dose dexamethasone in the rat: a model to study insulin resistance. Am J Physiol Endocrinol Metab Vol. 283, No. 2, pp. E367-373

Shamoon, H., Soman, V., \& Sherwin, R.S. (1980). The influence of acute physiological increments of cortisol on fuel metabolism and insulin binding to monocytes in normal humans. J Clin Endocrinol Metab Vol. 50, No. 3, pp. 495-501

Shao, J., Qiao, L., \& Friedman, J.E. (2004). Prolactin, progesterone, and dexamethasone coordinately and adversely regulate glucokinase and cAMP/PDE cascades in MIN6 beta-cells. Am J Physiol Endocrinol Metab Vol. 286, No. 2, pp. E304-310

Sood, A., \& Ismail-Beigi, F. (2010). Effect of dexamethasone on insulin secretion: examination of underlying mechanisms. Endocr Pract Vol. 16, No. 5, pp. 763-769

Stojanovska, L., Rosella, G., \& Proietto, J. (1990). Evolution of dexamethasone-induced insulin resistance in rats. Am J Physiol Vol. 258, No. 5 Pt 1, pp. E748-756

Swali, A., Walker, E.A., Lavery, G.G., Tomlinson, J.W., \& Stewart, P.M. (2008). 11 $\beta-$ Hydroxysteroid dehydrogenase type 1 regulates insulin and glucagon secretion in pancreatic islets. Diabetologia Vol. 51, No. 11, pp. 2003-2011

Thomas, C.R., Turner, S.L., Jefferson, W.H., \& Bailey, C.J. (1998). Prevention of dexamethasone-induced insulin resistance by metformin. Biochem Pharmacol Vol. 56, No. 9, pp. 1145-1150

Tomita, T., Visser, P., Friesen, S., \& Doull, V. (1984). Cortisone-induced islet cell hyperplasia in hamsters. Virchows Arch B Cell Pathol Incl Mol Pathol Vol. 45, No. 1, pp. 85-95

Turban, S., Liu, X., Ramage, L., Webster, S.P., Walker, B.R., Dunbar, D.R., Mullins, J.J., Seckl, J.R., \& Morton, N.M. (2012). Optimal elevation of beta-cell 11beta-hydroxysteroid dehydrogenase type 1 is a compensatory mechanism that prevents high-fat dietinduced beta-cell failure. Diabetes Vol. 61, No. 3, pp. 642-652

Ullrich, S., Berchtold, S., Ranta, F., Seebohm, G., Henke, G., Lupescu, A., Mack, A.F., Chao, C.M., Su, J., Nitschke, R., Alexander, D., Friedrich, B., Wulff, P., Kuhl, D., \& Lang, F. 
(2005). Serum- and glucocorticoid-inducible kinase 1 (SGK1) mediates glucocorticoidinduced inhibition of insulin secretion. Diabetes Vol. 54, No. 4, pp. 1090-1099

Ullrich, S., Zhang, Y., Avram, D., Ranta, F., Kuhl, D., Haring, H.U., \& Lang, F. (2007). Dexamethasone increases $\mathrm{Na}+\mathrm{K}+$ ATPase activity in insulin secreting cells through SGK1. Biochem Biophys Res Commun Vol. 352, No. 3, pp. 662-667

Wajngot, A., Giacca, A., Grill, V., Vranic, M., \& Efendic, S. (1992). The diabetogenic effects of glucocorticoids are more pronounced in low- than in high-insulin responders. Proc Natl Acad Sci U S A Vol. 89, No. 13, pp. 6035-6039

van Raalte, D.H., Nofrate, V., Bunck, M.C., van Iersel, T., Elassaiss Schaap, J., Nassander, U.K., Heine, R.J., Mari, A., Dokter, W.H., \& Diamant, M. (2010). Acute and 2-week exposure to prednisolone impair different aspects of beta-cell function in healthy men. Eur J Endocrinol Vol. 162, No. 4, pp. 729-735

van Raalte, D.H., Ouwens, D.M., \& Diamant, M. (2009). Novel insights into glucocorticoidmediated diabetogenic effects: towards expansion of therapeutic options? Eur J Clin Invest Vol. 39, No. 2, pp. 81-93

Wang, Z.L., Bennet, W.M., Wang, R.M., Ghatei, M.A., \& Bloom, S.R. (1994). Evidence of a paracrine role of neuropeptide- $Y$ in the regulation of insulin release from pancreatic islets of normal and dexamethasone-treated rats. Endocrinology Vol. 135, No. 1, pp. 200206

Vasavada, R.C., Gonzalez-Pertusa, J.A., Fujinaka, Y., Fiaschi-Taesch, N., Cozar-Castellano, I., \& Garcia-Ocana, A. (2006). Growth factors and beta cell replication. Int J Biochem Cell Biol Vol. 38, No. 5-6, pp. 931-950

Weinhaus, A.J., Bhagroo, N.V., Brelje, T.C., \& Sorenson, R.L. (2000). Dexamethasone counteracts the effect of prolactin on islet function: implications for islet regulation in late pregnancy. Endocrinology Vol. 141, No. 4, pp. 1384-1393

Wierup, N., Bjorkqvist, M., Kuhar, M.J., Mulder, H., \& Sundler, F. (2006). CART regulates islet hormone secretion and is expressed in the beta-cells of type 2 diabetic rats. Diabetes Vol. 55, No. 2, pp. 305-311

Willi, S.M., Kennedy, A., Wallace, P., Ganaway, E., Rogers, N.L., \& Garvey, W.T. (2002). Troglitazone antagonizes metabolic effects of glucocorticoids in humans: effects on glucose tolerance, insulin sensitivity, suppression of free fatty acids, and leptin. Diabetes Vol. 51, No. 10, pp. 2895-2902

Zakrzewska, K.E., Cusin, I., Stricker-Krongrad, A., Boss, O., Ricquier, D., Jeanrenaud, B., \& Rohner-Jeanrenaud, F. (1999). Induction of obesity and hyperleptinemia by central glucocorticoid infusion in the rat. Diabetes Vol. 48, No. 2, pp. 365-370

Zawalich, W.S., Tesz, G.J., Yamazaki, H., Zawalich, K.C., \& Philbrick, W. (2006). Dexamethasone suppresses phospholipase $C$ activation and insulin secretion from isolated rat islets. Metabolism Vol. 55, No. 1, pp. 35-42

Zhang, X., Yong, W., Lv, J., Zhu, Y., Zhang, J., Chen, F., Zhang, R., Yang, T., Sun, Y., \& Han, X. (2009). Inhibition of forkhead box O1 protects pancreatic $\beta$-cells against dexamethasone-induced dysfunction. Endocrinology Vol. 150, No. 9, pp. 4065-4073

Zwicker, G.M., \& Eyster, R.C. (1993). Chronic effects of corticosteroid oral treatment in rats on blood glucose and serum insulin levels, pancreatic islet morphology, and immunostaining characteristics. Toxicol Pathol Vol. 21, No. 5, pp. 502-508 